\title{
Review \\ Self-Replicating RNA Viruses for RNA Therapeutics
}

\author{
Kenneth Lundstrom \\ PanTherapeutics, Route de Lavaux 49, CH1095 Lutry, Switzerland; lundstromkenneth@gmail.com; \\ Tel.: +41-79-776-6351
}

Received: 16 November 2018; Accepted: 11 December 2018; Published: 13 December 2018

\begin{abstract}
Self-replicating single-stranded RNA viruses such as alphaviruses, flaviviruses, measles viruses, and rhabdoviruses provide efficient delivery and high-level expression of therapeutic genes due to their high capacity of RNA replication. This has contributed to novel approaches for therapeutic applications including vaccine development and gene therapy-based immunotherapy. Numerous studies in animal tumor models have demonstrated that self-replicating RNA viral vectors can generate antibody responses against infectious agents and tumor cells. Moreover, protection against challenges with pathogenic Ebola virus was obtained in primates immunized with alphaviruses and flaviviruses. Similarly, vaccinated animals have been demonstrated to withstand challenges with lethal doses of tumor cells. Furthermore, clinical trials have been conducted for several indications with self-amplifying RNA viruses. In this context, alphaviruses have been subjected to phase I clinical trials for a cytomegalovirus vaccine generating neutralizing antibodies in healthy volunteers, and for antigen delivery to dendritic cells providing clinically relevant antibody responses in cancer patients, respectively. Likewise, rhabdovirus particles have been subjected to phase I/II clinical trials showing good safety and immunogenicity against Ebola virus. Rhabdoviruses have generated promising results in phase III trials against Ebola virus. The purpose of this review is to summarize the achievements of using self-replicating RNA viruses for RNA therapy based on preclinical animal studies and clinical trials in humans.
\end{abstract}

Keywords: self-amplifying RNA virus; vaccine; cancer therapy; immunotherapy; neutralizing antibodies; protection against viral and tumor challenges; clinical trials

\section{Introduction}

Although drug development has strongly contributed to finding superior therapeutic efficacy, there is still space and need for further improvement. In addition to classic drug screening of small molecules, innovative modern approaches in biotechnology and genomics research have contributed to new therapeutic possibilities in the areas of vaccine development and gene and immunotherapy. In this context, RNA-based therapeutics have become an interesting alternative [1]. RNA-based drugs have been classified by mechanisms of action including antisense approaches of inhibition of mRNA translation, gene silencing with RNA interference, catalytically active ribozymes, protein binding RNA molecules, and aptamers for diagnostic and therapeutic applications. In this context, lipid-encapsulated nanoparticles containing double-stranded small interfering RNA (siRNA) have been applied for binding to transthyretin (TTR) mRNA causing degradation of TTR deposits present in patients with hereditary TTR-mediated amyloidosis [2]. This novel RNA interference-based drug, Patisiran (ONPATTRO ${ }^{\mathrm{TM}}$ ), has recently been approved in both the US and Europe as a single intravenous infusion. Recently, messenger RNAs (mRNAs) generated by in vitro transcription have become attractive targets for drug and vaccine development [3]. Two approaches for mRNA-based drugs have been taken based on ex vivo transfection of cells from patients or direct mRNA administration. In this context, preclinical and clinical studies have been conducted 
in the areas of cancer immunotherapy [4,5], vaccine development against infectious diseases [6,7], protein replacement [8], and gene editing [9].

Related to mRNA-based drug approaches, the employment of self-replicating RNA viruses has provided an interesting and attractive alternative to further enhance delivery and efficacy [10]. The unique feature of high-rate cytoplasmic replication combined with extreme transgene expression has made these RNA viruses the system of choice for RNA therapeutics. In this review, self-replicating vectors are described and their applications for preclinical studies and clinical trials are discussed.

\section{Self-Replicating RNA Viruses}

The common feature of self-replicating RNA viruses relates to their single-stranded RNA (ssRNA) genome surrounded by a capsid core structure and a protein envelope. Alphaviruses [11] and flaviviruses [12] possess a genome of positive polarity, whereas the genome of measles viruses (MVs) [13] and rhabdoviruses [14] as negative strand ssRNA. Expression vectors serving as templates for RNA transcription and recombinant viral particles have been engineered. Moreover, alphavirus vectors providing RNA replication can be utilized as plasmid DNA.

\subsection{Alphaviruses}

Alphaviruses belong to the family of Togaviridiae [15]. The most common alphaviruses engineered as expression vectors are based on Semliki Forest virus (SFV) [15], Sindbis virus (SIN) [16], and Venezuelan equine encephalitis virus (VEE) [17]. The alphavirus genome consists of four nonstructural genes (nsP1-4), responsible for RNA self-replication and the genes for the capsid and envelope proteins [11] (Figure 1A-C). Engineered alphavirus vectors generate replication-deficient and -proficient recombinant particles suitable for transgene expression in cell lines and in vivo [18]. Introduction of a CMV promoter upstream of the nsP genes allows direct transfection of plasmid DNA with self-replicating RNA capacity [19]. Due to the design of these alternative alphavirus vectors it is possible to conduct studies with naked RNA replicons, recombinant viral particles and layered DNA-RNA vectors.

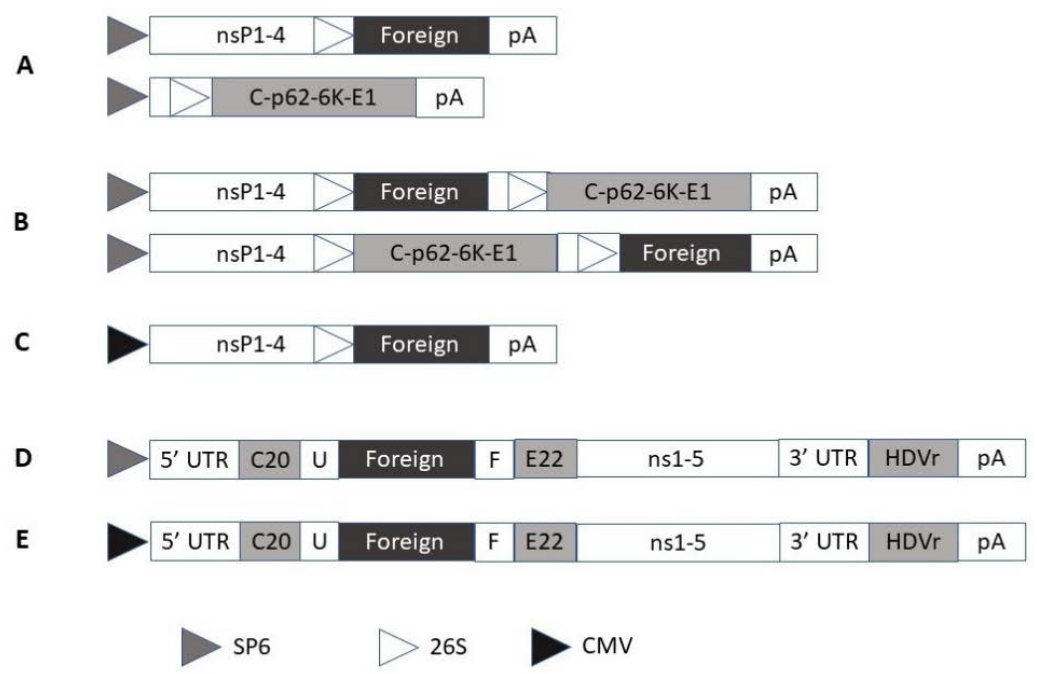

Figure 1. Self-replicating alphavirus and flavivirus vectors. (A) Replication-deficient alphavirus system with expression vector (above) and helper vector (below). (B) Replication-proficient alphavirus system including two alternative insertion sites. (C) DNA/RNA layered Semliki Forest virus (SFV) vector. (D, E) KUN vectors with SP6 and CMV promoters, respectively. 26S, subgenomic promoter; C20, first 20 amino acids of KUN C protein; CMV, cytomegalovirus; E22, last 22 amino acids of KUN E protein; F, Foot-and-mouth disease virus 2A autoprotease; HDVr, Hepatitis delta virus ribozyme; pA, polyadenylation signal; SP6, bacteriophage RNA polymerase; T7, phage T7 RNA polymerase promoter; $\mathrm{U}$, mouse ubiquitin sequence; $3^{\prime} \mathrm{UTR}, 3^{\prime}$ untranslated region; $5^{\prime} \mathrm{UTR}, 5^{\prime}$ untranslated region. 


\subsection{Flaviviruses}

In a similar way as for alphaviruses, flaviviruses also possess a ssRNA genome of positive polarity [12]. For instance, based on Kunjin virus (KUN), vectors have been engineered for the delivery of RNA, recombinant particles, and DNA plasmids [12] (Figure 1D-E). In contrast to alphaviruses, the gene of interest is not inserted downstream of the nonstructural genes, but between the first 60 nucleotides of the $\mathrm{C} 20$ core protein and the last 22 codons of the E22 envelope protein in frame with the viral polyprotein. Although the recombinant protein of interest is initially part of a large polyprotein processed into individual proteins, the remaining flanking regions can be removed by an FMDV-2A protease sequence introduced into the KUN vector [20]. In support of virus production, a packaging cell line has been engineered for KUN [21]. Other expression vectors based on flaviviruses such as West Nile virus [22,23], yellow fever virus [24,25], dengue virus [26,27], and tick-borne encephalitis virus $[28,29]$ have been generated.

\subsection{Measles Viruses}

The negative polarity of the MV ssRNA genome has required the engineering of packaging systems for the rescue of replicating MV from cloned DNA expression constructs [30]. Rescue of recombinant MV has been established in a helper cell line by reverse genetics [13]. Expression vectors carrying the MV structural proteins downstream of a T7 RNA polymerase promoter have been designed for the introduction of foreign genes between the phosphoprotein $(\mathrm{P})$ and the matrix protein (M) or alternatively between the hemagglutinin (HA) and the large protein (L) (Figure 2A). To generate recombinant MV particles, a helper cell line is transfected with recombinant MV constructs and a plasmid containing the MV polymerase L gene. Recombinant MVs are harvested three days after transfection when reaching $80-90 \%$ of their cytopathic effect.

\subsection{Rhabdoviruses}

Both rabies virus (RABV) [31] (Figure 2B) and vesicular stomatitis virus (VSV) [32] have been subjected to expression vector engineering. As for MV, the negative ssRNA genome of rhabdoviruses has required application of reverse genetics based on a recombinant vaccinia virus vector to establish efficient transgene expression. However, when the VSV N, P, and L genes were inserted downstream of a T7 promoter and an internal ribosome entry site (IRES), efficient recovery of VSV particles was obtained from transfected DNA in a vaccinia virus-free system [33]. Similarly, RABV virus vectors have been engineered, where the gene of interest has been introduced between the RABV N and $P$ genes [34]. Moreover, recovery of RABV from cloned cDNA has been achieved in a vaccinia virus-free reverse genetics system [35]. In another approach, chimeric virus-like particles (VLPs) with SFV RNA replicons encapsulated by the VSV glycoprotein (VSV-G) have been engineered, which provide additional biosafety [36].

\section{Preclinical Studies}

\subsection{Viral Diseases}

Self-replicating RNA virus vectors have been subjected to numerous preclinical immunization studies targeting infectious diseases (Table 1). In this context, Dengue virus has been targeted by immunization with MV expressing the domain III of Dengue virus envelope protein 2 (DV2), which elicited robust neutralizing antibodies in MV-susceptible mice [37]. Moreover, immunization with MV displaying domain III of DV1-4 not only generated neutralizing antibodies, but also provided protection against four Dengue virus serotypes in mice [38]. Similarly, much attention has been paid to vaccine development against Ebola virus. For instance, expression of Ebola glycoprotein (GP) from KUN [39] and VSV [40,41] vectors, has provided protection against Ebola virus challenges in nonhuman primates. Moreover, immunization with VEE-NP rendered mice resistant to Ebola infections in mice [42]. In another study, immunization with VEE vectors expressing Ebola GP and nucleoprotein (NP) was 
evaluated in BALB/c mice and two strains of guinea pigs [43]. Single administration of VEE-GP VLPs or a combination of VEE-GP and -NP VLPs provided protection of both mice and guinea pigs. In contrast, VEE-NP VLPs alone protected mice, but not guinea pigs. In a recent study, application of DNA/RNA layered self-replicating SFV vectors coexpressing Ebola GP and VP40 elicited both binding and neutralizing antibodies [44]. The immunogenicity was superior to a Modified vaccinia virus Ankara (MVA) vaccine and could be further enhanced by an MVA boost.

A

\begin{tabular}{|l|l|l|l|l|l|l|l|}
\hline N & P & Foreign & M & Fu & H & L & T7 term \\
\hline
\end{tabular}

\begin{tabular}{|l|l|l|l|l|l|l|l|}
\hline N & P & M & Fu & H & Foreign & L & T7 term \\
\hline
\end{tabular}

\begin{tabular}{|l|l|l|l|l|l|}
\hline N & Foreign & P & M & G & L \\
\hline
\end{tabular}

B

\begin{tabular}{|l|l|l|l|l|l|}
\hline N & P & M & G & Foreign & L \\
\hline
\end{tabular}

Figure 2. Self-replicating rhabdovirus and measles virus vectors. (A) Rabies virus vector with alternative insertion sites for foreign genes. (B) Measles virus vector with alternative insertion sites for foreign genes. CMV, cytomegalovirus; Fu, Measles virus fusion protein; $G$, Measles virus $G$ protein; $\mathrm{H}$, Measles virus hemagglutinin; L, Rabies or measles virus L protein; $\mathrm{M}$, Rabies or measles virus matrix protein; N: Rabies or measles virus nucleocapsid protein; P, Rabies P or measles virus phosphoprotein; T7, phage T7 RNA polymerase promoter; T7 term, phage T7 terminator sequence.

Related to hepatitis B virus (HBV), MV vectors expressing the hepatitis B surface antigen (HBsAg) were demonstrated to elicit humoral responses in MV-susceptible genetically modified mice and rhesus monkeys immunized with MV-HBsAg remained healthy [45]. In another study, SFV RNA replicons expressing VSV G, which generated virus-like vesicles (VLVs), were engineered to carry the HBV middle surface envelope glycoprotein (MHB) [46]. Immunization of mice resulted in $\mathrm{CD}^{+} \mathrm{T}$ cell responses, which showed higher magnitude and broader specificity in comparison to immunizations with recombinant protein and DNA. A single administration with MHB-VLVs protected mice from HBV challenges. In contrast, immunization with SFV VLVs expressing the HBV core protein (HBcAg) did not produce $\mathrm{CD}^{+} \mathrm{T}$ cell responses and no HBV protection.

Not surprisingly, the human immunodeficiency virus (HIV) has been subjected to vaccine development applying self-replicating RNA vectors. In this context, SFV vectors expressing the HIV Env gene were administered as plasmid DNA in mice and compared to a recombinant Env glycoprotein vaccine [47]. The humoral immune responses to the HIV-1 envelope were strongest from SFV recombinant particles compared to the other HIV Env vaccines tested. In another study, SFV RNA expressing the HIV-1 Env protein administered intramuscularly in mice generated Env-specific antibody responses in four out of five mice [48]. Recently, mice immunized with SFV vectors expressing the HIV Env/Gag/polRT genes either individually or in combination elicited significant $\mathrm{T}$ cell responses [49]. The immune responses were stronger for SFV VRPs than for RNA replicons. DNA based SFV vectors expressing Env and a Gag-Pol-Nef fusion protein have also been subjected to immunizations followed by heterologous boosts with MVA and/or HIV gp40 protein formulated in a glycopyranosyl lipid A (GLA-AF) adjuvant [50]. Immunization with $0.2 \mu \mathrm{g}$ of SFV DNA induced lower HIV-specific T cell and IgG responses than immunization with $10 \mu \mathrm{g}$ of SFV-DNA. However, the immune responses for the two doses were similarly efficient when boosting was performed with 
MVA or HIV gp40. Furthermore, a single low dose of SFV-DNA elicited superior immune responses compared to MVA or protein antigen alone.

Table 1. Examples of preclinical immunization with self-replicating RNA viruses targeting viral diseases.

\begin{tabular}{|c|c|c|c|c|}
\hline Indication & Target/Antigen & Vector & Response & Ref. \\
\hline \multirow{2}{*}{ Dengue } & DV2 & MV & Neutralizing Abs & [37] \\
\hline & DV1-4 & MV & Protection & {$[38]$} \\
\hline \multirow{3}{*}{ Ebola } & GP & KUN VLPs & Protection & [39] \\
\hline & GP & VSV & Protection & {$[40,41]$} \\
\hline & GP, NP & VEE VLPs & Protection & {$[42,43]$} \\
\hline \multirow{2}{*}{ HBV } & HBsAg & MV & Humoral Abs & [45] \\
\hline & MHB & SFV-VLVs & Protection & [46] \\
\hline \multirow{4}{*}{ HIV } & Env & SFV VLPs & Humoral response & [47] \\
\hline & Env & SFV RNA & Antibody response & [48] \\
\hline & Env/Gag/Pol & SFVVLPs/RNA & Ag-specific immune response & [49] \\
\hline & Env/GagPolNef & SFV DNA & T cell and IgG responses & [50] \\
\hline \multirow{4}{*}{ Influenza } & NP & SFV VLPs & Mucosal immune response & [51] \\
\hline & $\mathrm{HA}$ & VEE VLPs & Protection & [52] \\
\hline & $\mathrm{HA}, \mathrm{NP}$ & SFV VLPs & Protection & [53] \\
\hline & HA & VEE RNA & Protection & [54] \\
\hline \multirow{3}{*}{ Lassa } & Glycoprotein & VSV VLPs & Protection & [55] \\
\hline & GPC & VEE VLPs & Protection & {$[56]$} \\
\hline & Lassa & Lassa VLPs & Protection & [57] \\
\hline MERS-CoV & MERS-S & MV & Protection & {$[58]$} \\
\hline SARS-CoV & SARS-CoV GP & VEE VLPs & Protection & [59] \\
\hline MPV & MPV-F & VEE VLPs & Reduced viral load & [60] \\
\hline \multirow{3}{*}{ RSV } & RSFV-F & SFV-VLPS & Protection & [53] \\
\hline & RSV-F & VEE VLPS & Reduced viral load & [60] \\
\hline & RSV-F & VEE LNPs & Protection & [61] \\
\hline \multirow{2}{*}{ SIV } & Gag-pol & KUN VLPs & Protection & [62] \\
\hline & SIVmacJ5 & SFV VLPs & Cytotoxic T cell response & [63] \\
\hline TBEV & GP & SFV VLPs & Protection & [53] \\
\hline \multirow[b]{2}{*}{ VEE } & VEE replicon & VEE miRNA & VEE inhibition & [64] \\
\hline & VEE RdRp & VEE miRNA & VEE inhibition & [65] \\
\hline
\end{tabular}

Ag, antigen; DV, Dengue virus envelope protein; GCP, glycoprotein; GP, glycoprotein; HA, hemagglutinin; HBV, hepatitis B virus; HBsAg, hepatitis B surface antigen; HIV, human immunodeficiency virus; KUN, Kunjin virus; LNPs, lipid nanoparticles; MERS-CoV, Middle East respiratory syndrome coronavirus; MERS-S, Middle East respiratory syndrome spike protein; MHB, HBV middle surface envelope glycoprotein; miRNA, micro RNA; MV, measles virus; NP, nucleoprotein; RdRp, RNA-dependent RNA polymerase; RSV, respiratory syncytial virus; SARS-CoV, severe acute respiratory syndrome corona virus; SFV, Semliki Forest virus; SIV. Simian immunodeficiency virus; TBEV, Tick-borne encephalitis virus; VEE, Venezuelan equine encephalitis virus; VLPs, virus-like particles; VLVs, virus-like vesicles; VSV, vesicular stomatitis virus.

Much attention has also been paid to vaccine development against influenza virus. For instance, SFV-based expression of influenza virus nucleoprotein (NP) elicited systemic immune responses after intravascular injections and mucosal immune responses after intranasal administration [51]. Moreover, VEE particles carrying the hemagglutinin (HA) gene from the Hong Kong influenza A isolate $(\mathrm{A} / \mathrm{HK} / 156 / 97)$ were administered to chicken embryos and young chicks [52]. When birds were challenged with a lethal dose of influenza virus, inoculation in ovo and at 1 day of age provided partial protection, while a single at week 2 resulted in complete protection. Similarly, recombinant SFV particles expressing influenza HA and NP provided protection against challenges with influenza virus [53]. Recently, in a comparison between synthetic mRNA and self-replicating VEE 
RNA expressing influenza HA [54], equivalent protection was obtained for both strategies. However, only $1.25 \mu \mathrm{g}$ of self-replicating RNA was needed, whereas $80 \mu \mathrm{g}$ of mRNA (64-fold more) material was required. Protection was observed for influenza strains H1N1, H3N2 (X31), and B (Massachusetts). Moreover, a trivalent formulation protected against sequential H1N1 and H3N2 challenges.

Lassa viruses have also been subjected to vaccine development. For instance, VSV vectors expressing Lassa virus glycoproteins demonstrated protection of guinea pigs challenged with Lassa virus originating in Liberia, Mali, and Nigeria [55]. Moreover, complete protection was also obtained in macaques after challenge with a lethal dose of the Liberian Lassa virus isolate. Furthermore, a bicistronic VEE vector expressing Lassa virus glycoproteins from distantly related clades I and IV from individual $26 \mathrm{~S}$ subgenomic promoters elicited immune responses in vaccinated mice and provided protection against Lassa virus challenges [56]. Interestingly, a vaccine based on Lassa virus replicon particles devoid of the essential Lassa virus glycoprotein gene has been evaluated in a guinea pig model [57]. In this approach, nonspreading Lassa virus replicon particles produced in Vero cells were administered to guinea pigs showing protection against fever, weight loss, and lethality.

Related to Middle East respiratory syndrome coronavirus (MERS-CoV), replication competent MV was used for the expression of the full-length spike glycoprotein (MERS-S) and a truncated soluble variant, MERS-solS [58]. Both vaccine candidates induced robust levels of both MV- and MERS-CoV-neutralizing antibodies in a prime-boost regimen in mice. Furthermore, these immune responses rendered protective capacity in vaccinated mice. Likewise, VEE replicon particles were applied for vaccine development against severe acute respiratory syndrome coronavirus (SARS-CoV) [59]. The study demonstrated that aged BALB/c mice vaccinated with attenuated VEE VRPs (VRP3014) failed to protect from SARS-CoV disease, while wild-type VEE VRPs (VRP3000) gave protection against SARS-CoV.

VEE VLPs have been applied for the expression of human metapneumovirus (hMPV) and respiratory syncytial virus (hRSV) fusion (F) proteins [60]. Immunization of African green monkeys generated RSV and MPV F-specific antibodies, respectively. Moreover, lower levels of viral genomes were detected in nasopharyngeal and bronchoalveolar lavage fluids. In another study, VEE vectors have been employed for vaccine development with a focus on replicon delivery [61]. In this context, VEE VLPs, were compared to naked RNA and RNA encapsulated in lipid nanoparticles (LNPs). Reporter gene expression in mice revealed 10-fold higher levels of RNA-LNP delivery compared to naked RNA after intramuscular administration despite administration of only $0.1 \mu \mathrm{g}$ (RNA-LNPs) compared to $1.0 \mu \mathrm{g}$ (RNA). Moreover, comparison of in vivo expression showed the highest levels from plasmid DNA, followed by RNA-LNPs, and the lowest expression levels detected after RNA delivery. In contrast, RSV-F specific antibody titers were similar for $1 \times 10^{6} \mathrm{IU}$ VEE particles and $0.1 \mu \mathrm{g}$ RNA-LNPs, whereas $1 \mu \mathrm{g}$ naked RNA generated 10-fold lower titers. Electroporation of $20 \mu \mathrm{g}$ DNA provided similar antibody responses as for $0.1 \mu \mathrm{g}$ RNA-LNPs. Delivery of $0.1 \mu \mathrm{g}$ DNA-LNPs was inefficient generating 1000-fold lower titers than for RNA-LNPs.

Several studies have been carried out for simian immunodeficiency virus (SIV) vaccines based on self-replicating RNA viruses. In this context, four different KUN-based SIVmac 239 gag vaccines were evaluated in mice [62]. In comparison, a modified gag-pol gene construct was superior to wild-type gag, RNA-optimized gag, and codon-optimized gag in immune response induction and protection against SIV challenges in mice. In another study, SFV and MVA expressing SIVmacJ5 env, gag-pol, nef, rev, and tat were evaluated in macaques [63]. SFV-SIVmac or MVA-SIVmac immunizations alone elicited low or undetectable cytotoxic T cell responses. However, two immunizations with SFV-SIVmac followed by a boost with MVA-SIVmac increased both antibody and high T cell responses. However, no protection against SIV challenges was achieved.

In support of vaccine development, gene silencing has been applied to some extent. In this context, micro-RNA (miRNA) sequences targeting RNA replication were introduced in a VEE helper vector used for replicon particle production [64]. As cellular miRNAs downregulates replicon RNA replication in vivo, efficient VEE particle production can be restored by addition of miRNA-specific inhibitors, 
which can contribute to future therapeutic applications. Moreover, inhibition of VEE replication was achieved in BHK cells by introduction of five artificial miRNAs targeting the RNA-dependent RNA polymerase (RdRp) [65].

\subsection{Cancer}

Similar to viral diseases, there are numerous preclinical studies carried out for cancer prevention and therapy (Table 2). In this context, retargeted MV vectors carrying both CD46 and signaling lymphocyte activation molecule (SLAM) incorporated in the HA protein in combination with the display of a single-chain antibody against epidermal growth factor receptor (EGFR) at the $\mathrm{C}$ terminus of HA [66]. It was demonstrated that the retargeted MV presented potent antitumor activity against EGFR or EGFRvIII primary glioblastoma cell lines. Moreover, intratumoral administration in glioblastoma xenografts provided tumor regression and significant prolongation of survival. Likewise, SFV vectors expressing Endostatin were compared to in vivo administration of SFV-LacZ, and retrovirus GCsap-Endostatin in mice bearing B16 brain tumors [67]. SFV-Endostatin provided very significant inhibition of tumor growth. Furthermore, in contrast to SFV-LacZ and GCsap-Endostatin, treatment with SFV-Endostatin generated a marked reduction of intratumoral vascularization. Additionally, 3-fold higher endostatin serum levels were observed for SFV-Endostatin than GCsap-Endostatin, indicating inhibition of angiogenesis and could provide new means for brain tumor therapy. In another approach, neuron-targeting miRT124 sequences were introduced into the SFV4 strain, which displayed increased oncolytic potency in CT-2A murine astrocytoma cells and in human glioblastoma cell lines [68]. A single intraperitoneal injection of SFV4-miRT124 showed virus replication in tumors, significant tumor growth inhibition, and improved survival in C57BL/ 6 mice implanted with CT-2A orthotopic gliomas.

Related to breast cancer, the Edmonston MV strain was engineered to express the carcinoembryonic antigen (CEA) [69]. The MV-CEA vector showed significant cytopathic effect in several breast cancer cell lines such as MDA-MB-231, MCF7, and SkBr3. Intravenous administration in BALB/c nude mice with MDA-MB-231 xenografts resulted in statistically significant delay in tumor growth and prolonged survival. In another approach, SIN and Adenovirus (Ad) vectors expressing the rat HER2/neu gene were subjected to immunization studies in mice [70]. Inhibition of A2L2 tumor cells was detected when animals were immunized with SIN or Ad prior to tumor challenge. In contrast, vaccination two days after tumor challenge was ineffective for both SIN and Ad. On the other hand, when SIN-neu immunization was followed by Ad-neu vaccination in a prime-boost protocol, the survival rate was significantly improved in mice intravenously challenged with tumor cells. The susceptibility of dendritic cells (DCs) to VEE-encouraged studies on therapeutic efficacy in animal models [71]. Immunization of DCs transduced with VEE recombinant particles expressing a truncated version of neu induced robust neu-specific $\mathrm{CD} 8^{+} \mathrm{T}$ cell and anti-neu IgG responses. A single administration of VEE-DCs resulted in regression of large established tumors in mice. Similarly, recombinant SFV particles carrying the vascular endothelial growth factor receptor-2 (VEGFR-2) gene were subjected to immunization studies in mice implanted with CT26 colon carcinoma and 4T1 metastasizing mammary carcinoma [72]. Both prophylactic immunization and therapeutic treatment resulted in inhibition of tumor growth and the spread of metastases. Furthermore, tumor angiogenesis was significantly inhibited. Co-immunization with SFV particles expressing VEGFR-2 and interleukin-12 (IL-12) abrogated both immune responses and tumor inhibition. In contrast, co-immunization with SFV-VEGFR-2 and SFV-IL-4 particles elicited higher titers of anti-VEGFR-2 antibodies and generated superior survival rates. In another approach, noncytopathic KUN VLPs expressing the granulocyte colony-stimulating factor (G-CSF) were subjected to intratumoral administration [73]. In mice implanted with aggressive subcutaneous CT26 colon carcinomas and B16-OVA melanomas cure was observed in more than $50 \%$ of animals. It was further established that tumor regression was associated with the induction of anticancer $\mathrm{CD}^{+} \mathrm{T}$ cells. Furthermore, treatment of subcutaneous CT26 tumors also led to regression of CT26 lung metastases. 
In another approach, SFV-LacZ RNA was evaluated in mice implanted with CT26 colon tumors [74]. A single intramuscular injection of $0.1 \mu \mathrm{g}$ SFV-LacZ RNA elicited antigen-specific antibody and $\mathrm{CD}^{+} \mathrm{T}$ cell responses. Protection against tumor challenges was achieved in pre-immunized animals and therapeutic vaccination prolonged the survival of mice with preexisting tumors. Interestingly, replicon RNA did not elicit significantly more model antigen than conventional DNA vaccines in vitro, while the enhanced in vivo efficacy correlated with a caspase-dependent apoptotic cell death.

Table 2. Examples of preclinical immunization studies of self-replicating RNA viruses targeting cancers.

\begin{tabular}{|c|c|c|c|c|}
\hline Cancer & Target/Antigen & Vector & Response & Ref. \\
\hline \multirow{3}{*}{ Brain } & SLAM, EGFR & MV & Tumor regression & {$[66]$} \\
\hline & Endostatin & SFV VLPs & Tumor inhibition & [67] \\
\hline & miR124 & SFV VLPs & Prolonged survival & [68] \\
\hline \multirow{4}{*}{ Breast } & CEA & MV & Prolonged survival & [69] \\
\hline & HER2/neu & SIN DNA & Prolonged survival & [70] \\
\hline & $\Delta$ neu & $\mathrm{VEE}+\mathrm{DCs}$ & Tumor regression & [71] \\
\hline & VEGFR-2 & SFV VLPs & Tumor inhibition & [72] \\
\hline \multirow{3}{*}{ Colon } & VEGFR-2 & SFV VLPs & Tumor inhibition & [72] \\
\hline & G-CSF & KUN VLPs & Tumor regression & [73] \\
\hline & LacZ & SFV RNA & Prolonged survival & [74] \\
\hline \multirow{5}{*}{ Cervical } & HPV16 E7 & VEE VLPs & Tumor prevention & [75] \\
\hline & HPV E6,7 & SFV VLPs & Tumor eradication & [76] \\
\hline & HPV E6, E7 & SFV DNA & Tumor eradication & [77] \\
\hline & HPV E6,7 & $\mathrm{SFV}+\mathrm{I}$ & >Antitumor activity & [78] \\
\hline & HPV E6,7 & SFV + I + Sun & Tumor-free mice & [79] \\
\hline \multirow{4}{*}{ Lung } & Dengue & Dengue & Lung susceptibility & [80] \\
\hline & EGFP & SFV VLPs & Tumor regression & [81] \\
\hline & EGFP & SFV(VA7) & Prolonged survival & [82] \\
\hline & SLAM & MV & Tumor suppression & [83] \\
\hline \multirow{7}{*}{ Melanoma } & G-CSF & KUN VLPs & Tumor regression & [73] \\
\hline & SIINFEKL & YFV & Tumor regression & [84] \\
\hline & TRP-2 & VEE & Prolonged survival & [85] \\
\hline & TRP-2 & $\mathrm{VEE}+\mathrm{mAbs}$ & Tumor regression & [86] \\
\hline & VEGFR2, IL12 & SFV DNA & Tumor regression & [87] \\
\hline & Surv, $\beta$-hCG & Combination & Prolonged survival & \\
\hline & VSV & VSV-GP & Prolonged survival & [88] \\
\hline \multirow{3}{*}{ Ovarian } & VSV & VSV-GP + Rux & Oncolytic activity & [89] \\
\hline & IL12 & $\mathrm{SIN}+\mathrm{CPT}-11$ & Long-term survival & [90] \\
\hline & OVA & $\mathrm{SFV}+\mathrm{VV}$ & Antitumor response & [91] \\
\hline \multirow{3}{*}{ Pancreatic } & VSV & VSV & PDA susceptibility & [92] \\
\hline & VSV & VSV + Rux & HPAF-II susceptible & [93] \\
\hline & SLAM & MV & Tumor suppression & [94] \\
\hline \multirow{5}{*}{ Prostate } & CEA & MV & Prolonged survival & [95] \\
\hline & PSMA & VEE & Prolonged survival & [96] \\
\hline & STEAP & VEE & Prolonged survival & [97] \\
\hline & PSCA & VEE & Prolonged survival & [98] \\
\hline & VSV & VSV-GP & Long-term remission & [99] \\
\hline
\end{tabular}

CEA, carcinoembryonic antigen; CPT-11, irinotecan; EGFP, enhanced green fluorescent protein; EGFR, epidermal growth factor receptor; G-CSF, granulocyte colony-stimulating factor; HPV, human papilloma virus; I, irradiation; KUN, Kunjin virus; miRNA, micro RNA; mAbs, monoclonal antibodies; MV, measles virus OVA, ovalbumin; PSCA, prostate stem cell antigen; PSMA, prostate-specific membrane antigen; Rux, ruxolitinib; SFV, Semliki Forest virus; SIN, Sindbis virus; SIINFEKL, chicken ovalbumin epitope; SLAM, signaling lymphocyte activation molecule; STEAP, six-transmembrane epithelial antigen of the prostate; Sun, sunitinib; TRP-2, tyrosine-related protein-2; VEE, Venezuelan equine encephalitis virus; VEGFR-2, vascular endothelial growth factor receptor-2; VLPs, virus-like particles; VSV, vesicular stomatitis virus; VV, vaccinia virus. 
Related to cervical cancer, VEE particles were applied for the expression of human papilloma virus-16 (HPV16) E7 protein [75]. Immunization of mice elicited class I-restricted CD8 ${ }^{+} \mathrm{T}$ cell responses and prevented tumor development in mice. Moreover, vaccination resulted in efficient elimination of 7 -day established tumors in $67 \%$ of tumor-bearing animals. In another study, a fusion protein of HPV E6 and E7 was expressed from an SFV vector containing a translation enhancer from the SFV capsid gene [76]. Tumor-bearing mice immunized with SFV-HPV E6/7 particles showed regression and complete elimination of established tumors. Moreover, long-term high level cytotoxic T lymphocyte activity was observed lasting up to 340 days. Recently, a DNA-based SFV expressing HPV E6/7 was subjected to intradermal administration followed by electroporation in mice, which generated efficient therapeutic antitumor immunity [77]. In comparison, a conventional DNA vaccine did not prevent tumor growth. However, a 200-fold lower equimolar dose of $0.05 \mu \mathrm{g}$ of SFV-HPV E6/7 rendered $85 \%$ of immunized mice tumor-free. Combination therapy has also been applied for SFV-HPV E6,7 together with local low-dose irradiation [78]. Local low-dose tumor irradiation alone generated a 2-fold increase of intratumoral $\mathrm{CD} 8^{+} \mathrm{T}$ cells. However, combination with SFV-HPV 6,7 particle immunization resulted in a 10-fold intratumoral $\mathrm{CD}^{+} \mathrm{T}$ cell increase and the number of $\mathrm{CD} 8^{+} \mathrm{T}$ cells specific for the E7 epitope was enhanced by more than 20-fold. Irradiation also upregulated chemokines and the combination therapy provided a strong increase in the ratio of antitumoral to immune suppressive cells, thereby changing the intratumoral immune balance in favor of antitumor activity. Furthermore, a triple treatment combination regimen was established with $40 \mathrm{mg} / \mathrm{kg}$ sunitinib, a single low-dose (14 Gy) tumor irradiation, and SFV-HPV E6,7 immunization [79]. This treatment dramatically changed the intratumoral compartment by strongly enhancing the immunotherapeutic antitumor activity, inhibiting tumor growth, and providing $100 \%$ tumor-free survival of mice with tumor xenografts.

Related to lung cancer, it has been demonstrated that Dengue virus is able to infect and replicate in human primary lung epithelium and several lung cancer cell lines [80]. The susceptibility of SW1573, A549, H1435, H23, H520, and Bes2B cell lines was shown. Furthermore, Dengue infections significantly increased expression levels of IL-6 and RANTES, consistent with findings in Dengue hemorrhagic fever patients. Moreover, SFV-EGFP vectors have been shown to induce apoptosis in human non-small cell lung carcinoma H358a cells and to inhibit the growth of developing H358a spheroids [81]. Intratumoral SFV-EGFP injection of nu/nu mice with H358a tumor xenografts induced apoptosis, antitumor activity, and provided complete tumor regression in some cases. In another study, replication-competent SFV(VA7)-EGFP particles, based on the avirulent SFV A7(74) strain, were locally administered in nude mice implanted with A549 adenocarcinoma lung cells [82]. In comparison to a second generation conditionally-replicating Ad vector (Ad5-Delta24TK-GFP). SFV(VA7)-EGFP provided superior survival rates in mice. However, systemic delivery was not able to elicit significant immune responses. Among rhabdoviruses, VSV particles expressing interferon $\beta$ (IFN $\beta$ ) were subjected to intratumoral injections in mice with $\mathrm{H} 2009$ and A549 xenografts, which reduced tumor growth [100]. Furthermore, intratumoral administration of VSV-IFN $\beta$ into syngeneic LM2 lung tumors grown in flanks of A/J mice, provided prolonged survival and cure in 30\% of mice. In the context of MV, vectors expressing SLAM (rMV-SLAMblind) showed susceptibility to nine human lung cancer cell lines [83]. Tumor suppression was detected in mice with lung xenografts after injection of rMV-SLAMblind and scattered tumor masses grown in the lungs were targeted.

In the context of melanoma, several preclinical studies have been conducted. For instance, yellow fever virus (YFV) expressing a cytotoxic T lymphocyte epitope derived from chicken ovalbumin (SIINFEKL) was evaluated in mice [84]. Immunization resulted in SIINFEKL-specific $\mathrm{CD}^{+}$lymphocytes and induced protection against challenges with malignant melanoma cells. Moreover, YVF vaccination induced regression of established solid tumors and pulmonary metastases. Additionally, alphavirus vectors have been applied for melanoma treatment. VEE particles expressing tyrosine-related protein-2 (TRP-2). Evaluation in a B16 mouse transplantable melanoma model revealed humoral immune responses, durable antitumor effect, and prolonged survival [85]. Furthermore, VEE-TRP-2 particles were combined with either antagonist anti-CTL antigen-4 (CTLA-4) or 
agonist anti-glucocorticoid-induced TNF family-related (GITR) gene immunomodulatory monoclonal antibodies (mAbs) [86]. Administration of VEE-TRP-2 and anti-CTLA-4 or anti-GITR mAbs induced complete regression in 50\% and $90 \%$ of mice, respectively. In a DNA-based co-immunization of an SFV vector expressing VEGR2 and IL12 and another SFV vector targeting survivin and $\beta$-hCG antigens elicited efficient humoral and cellular immune responses against survivin, $\beta-\mathrm{hCG}$, and VEGFR2 [87]. In comparison to immunization with each SFV DNA vector alone, the combined vaccine showed superior inhibition of tumor growth and prolonged survival in a B16 melanoma mouse model. In another study, VSV pseudotyped (VSV-GP) with the non-neurotropic envelope glycoprotein of the lymphocytic choriomeningitis virus (LCMV) effective for treatment of malignant glioblastoma [101], demonstrated efficient infection and killing of human, mouse, and canine melanoma cell lines [88]. Moreover, immunization of mice with VSV-GP prolonged survival in both xenograft and syngeneic mouse models. However, long-term tumor remission was achieved in only a few mice. The VSV-GP oncolytic virus has also been applied for ovarian cancer cell lines and mice with xenografts [89]. Oncolytic activity was detected in ovarian cancer cell lines as well as response to and production of type I interferon. Similarly, oncolytic activity was observed in vivo, although remission was temporary. However, combination therapy with ruxolitinib enhanced the response in both subcutaneous and orthotopic xenograft models. Furthermore, alphaviruses have been subjected to preclinical studies on combination therapy in ovarian cancer. For instance, combination of SIN and topoisomerase inhibitor irinotecan (CPT-11) provided long-term survival in 35\% of severe combined immunodeficiency (SCID) mice with aggressively growing ES2 human ovarian cancer [90]. In contrast, neither SIN-IL12 immunization nor CPT-11 treatment alone supported long-term survival. In another approach, it was demonstrated that immunization with vaccinia virus (VV)-ovalbumin (OVA) followed by administration of SFV-OVA or vice versa enhanced OVA-specific CD8 ${ }^{+} \mathrm{T}$ cell immune responses in tumor bearing mice [91]. Moreover, immunization enhanced antitumor effects against murine ovarian surface epithelial carcinoma (MOSEC) tumors.

Pancreatic cancer has also been the target of preclinical studies. In this context, 13 pancreatic ductal adenocarcinoma (PDA) cell lines showed superior oncolytic abilities of VSV compared to conditionally replicative adenovirus (CRAd), Sendai virus, and RSV [92]. Moreover, similar oncolytic activity was confirmed in vivo. Moreover, as certain PDA cell lines such as HPAF-II cells have demonstrated low susceptibility to VSV, it was revealed that the resistance could be broken by addition of ruxolitinib and Polybrene or DEAE-dextran, which should facilitate the treatment of tumors resistant to VSV therapy [93]. Additionally, MV-SLAMblind showed to efficiently infect and kill pancreatic cell lines with nectin-4 expressed on the cell surface [94]. Moreover, intratumoral administration of MV-SLAMblind generated substantial growth suppression of implanted KLM1 and Capan-2 xenografts in SCID mice.

Related to prostate cancer, self-replicating RNA vectors have been applied for studies in several animal models. In this context, MV was shown to efficiently infect and kill PC-3, DU-145, and LnCaP prostate cancer cell lines, and was applied for expression of CEA [95]. Significant tumor growth delay and prolonged survival were observed in a subcutaneous PC-3 xenograft model after intratumoral administration of $6 \times 10^{6} \mathrm{TCID}_{50}$ of MV-CEA. In another approach, VEE particles expressing prostate-specific membrane antigen (PSMA) were applied for immunization of mice and rabbits [96]. A single injection of $2 \times 10^{5}$ infectious units (IU) of VEE-PSMA was compared to immunization with purified PSMA protein. The VEE-based approach provided stronger immune responses than adjuvant PSMA protein. Furthermore, the immunogenic doses were well-tolerated. VEE particles have also been applied for expression of six-transmembrane epithelial antigen of the prostate (STEAP) [97]. Immunization of mice demonstrated specific $\mathrm{CD}^{+} \mathrm{T}$ cell responses and prolonged survival rate. Similarly, immunization with VEE particles expressing prostate stem cell antigen (PSCA) induced long-term protection against prostate cancer in prostate cancer-prone transgenic adenocarcinoma mouse prostate (TRAMP) mice [98]. Vaccinated mice showed a 90\% survival rate at 12 months of age, while control mice had either succumb to prostate cancer or presented 
heavy tumor loads. Finally, the pseudotyped VSV-GP particles have been evaluated in prostate cancer mouse models [99]. Intratumoral injection provided long-term remission and most interestingly, also remission of subcutaneous tumors and bone metastases after intravenous administration.

\section{Clinical Trials}

Self-replicating RNA viruses have been subjected to a limited number of clinical trials (Table 3). In this context, alphaviruses have been subjected to few clinical trials, so far. For instance, VEE particles expressing CMV gB or a PP65/IE1 fusion protein were applied for a randomized, double-blind phase I clinical trial in CMV seronegative individuals [102]. Intramuscular or subcutaneous administration was well-tolerated with no clinically important changes and direct IFN- $\gamma$ ELISPOT responses to CMV antigens were detected in all 40 vaccinated subjects. Moreover, immunization elicited neutralizing antibody and multifunctional $\mathrm{T}$ cell responses against all three CMV antigens. In another study, healthy HIV-negative volunteers were subjected to double-blind, randomized, placebo-controlled phase I trials in the United States and South Africa applying VEE expressing a nonmyristoylated form of Gag [103]. Subcutaneous administration of VEE-Gag was well-tolerated, but exhibited only modest local immune responses with low levels of binding antibodies and $\mathrm{T}$ cell responses. Although five serious adverse events were reported none were considered to be related to the administered vaccine. VEE particles capable of efficiently infecting DCs were employed for the expression of CEA in a clinical trial in patients with advanced cancer [104]. Intramuscular doses of $4 \times 10^{7}$ IU to $4 \times 10^{8}$ IU of VEE-CEA particles were given every three weeks for four immunizations. Repeated immunization induced clinically relevant CEA-specific $\mathrm{T}$ cell and antibody responses. The antibody-dependent cellular toxicity against tumor cells from human colorectal cancer metastases were mediated by CEA-specific antibodies. Moreover, longer overall survival was observed in patients with CEA-specific T cell responses. Propagation-defective VEE particles expressing the PSMA have also been subjected to a phase I clinical trial in patients with castration resistant metastatic prostate cancer (CRPC) [105]. Five doses of either $0.9 \times 10^{7} \mathrm{IU}$ or $3.6 \times 10^{7} \mathrm{IU}$ of VEE-PSMA were administered to patients with CRPC metastatic to the bone. Vaccinations were well-tolerated at both doses although only weak PSMA-specific signals were detected. Although neither clinical benefit nor robust immune responses were achieved, the elicited neutralizing antibodies suggest that dosing was suboptimal. In another approach, SFV particles expressing IL-12 (LipoVIL12) were encapsulated in liposomes, which provided passive tumor targeting and protection against host immune recognition [106]. LipoVIL12 was intravenously administered to melanoma and kidney carcinoma patients in a phase I clinical trial. Patients receiving LipoVIL12 showed transient (five days) up to 10-fold increased IL-12 plasma levels. The encapsulation enhanced tumor targeting and prevented host immune recognition after repeated injections. Furthermore, no toxicity was related to the treatment and the maximum tolerated dose (MTD) was determined as $3 \times 10^{9}$ particles per $\mathrm{m}^{2}$.

Several VSV-based clinical trials have been conducted [107]. Two placebo-controlled, double-blind, dose-escalation phase I trials have been performed with recombinant VSV particles expressing the glycoprotein of a Zaire strain of Ebola virus [108]. A total of 78 volunteers received one of three doses $\left(3 \times 10^{6}, 2 \times 10^{7}\right.$ or $\left.1 \times 10^{8} \mathrm{pfu}\right)$ of VSV-ZEBOV to assess safety and immunogenicity of the vaccination. Some adverse event such as injection-site pain, fatigue, myalgia, and headache occurred. Lower titers were observed at day 28 for the dose of $3 \times 10^{6} \mathrm{pfu}$ in comparison to the other two doses. 
Table 3. Examples of clinical trials applying self-replicating RNA viruses.

\begin{tabular}{|c|c|c|c|c|}
\hline Disease & Vector/Antigen & Phase & Response & Ref. \\
\hline CMV & VEE-gB/pp65 & Phase I & CMV-spec Abs & [102] \\
\hline HIV & VEE-Gag & Phase I & Low level Ab responses & [103] \\
\hline \multirow{9}{*}{ Ebola } & VSV-ZEBOV & Phase I & Safe, $\mathrm{Ab}$ responses & [108] \\
\hline & VSV $\Delta \mathrm{G}-Z E B O V$ & Phase I & Safe, sustainable Ab titers & [109] \\
\hline & VSV-ZEBOV & Phase I & $\begin{array}{l}\text { Safe, cellular immune } \\
\text { responses }\end{array}$ & [110] \\
\hline & VSV-ZEBOV & Phase I/II & $\begin{array}{c}\text { Reduced dose, } \\
\text { better tolerability }\end{array}$ & [111] \\
\hline & VSV $\Delta G-Z E B O V$ & Phase III & $\mathrm{Ab}$ responses & [112] \\
\hline & VSV-ZEBOV & Phase III & $\begin{array}{c}\text { Safe, efficient } \\
\text { EBV prevention }\end{array}$ & [113] \\
\hline & VSV-ZEBOV & Phase III & $\begin{array}{l}\text { Safe, substantial EBV } \\
\text { protection }\end{array}$ & [114] \\
\hline & VSV-ZEBOV & Phase II/III & $\begin{array}{l}\text { Safe, no EBV cases, } \\
\text { no SAEs }\end{array}$ & [115] \\
\hline & VSV $\triangle$ G-ZEBOV & Phase III & No EBV related SAEs & [116] \\
\hline Pancreatic CA & VEE-CEA & Phase I & $\begin{array}{c}\text { CEA-spec Abs; } \\
\text { prolonged survival }\end{array}$ & [104] \\
\hline CRPC & VEE-PSMA & Phase I & Neutralizing Abs & [105] \\
\hline CTCL & MV-EZ & Phase I & $\begin{array}{l}\text { Regression of } \\
\text { CTCL lesions }\end{array}$ & [117] \\
\hline Melanoma & LipoVIL12 & Phase I & Safe tumor targeting & [106] \\
\hline Kidney CA & LipoVIL12 & Phase I & Safe tumor targeting & [106] \\
\hline Ovarian CA & MV-CEA & Phase I & Stable disease & [118] \\
\hline Glioblastoma & MV-CEA & Phase I & No dose-limiting toxicity & [119] \\
\hline Myeloma & MV-NIS & Phase I & $\begin{array}{l}\text { Complete response in } \\
\text { one patient }\end{array}$ & [120] \\
\hline
\end{tabular}

Abs, antibodies; CA, cancer; CEA, carcinoembryonic antigen; CMV, cytomegalovirus; CRPC, castration resistant metastatic prostate cancer; CTCL, cutaneous T cell lymphoma; EBV, Ebola virus disease; HIV, human immunodeficiency virus; LipoVIL12, liposome encapsulated SFV-IL21 particles; MV, measles virus; MV-EZ, measles virus Edmonston Zagreb; NIS, sodium iodide symporter; PSMA, prostate-specific membrane antigen; SEAs, serious adverse events; SFV, Semliki Forest virus; VEE, Venezuelan equine encephalitis virus; VSV, vesicular stomatitis virus; ZEBOV, glycoprotein of Zaire Ebola virus.

Furthermore, a second dose at day 28 significantly increased the antibody titers at day 56, but the effect disappeared after 6 months. In another randomized, dose-ranging, observer-blind, placebo-controlled phase I trial, 40 participants received the attenuated VSV $\Delta G-Z E B O V-G P$ vaccine [109]. No serious adverse events were encountered. All vaccinees developed immune responses comparable across all doses applied. Sustainable IgG titers were detectable throughout the whole study (180 days). Furthermore, another phase I study with VSV-ZEBOV showed good tolerance, no vaccine-related adverse events, and superior cellular immune responses and stronger interlocked cytokine networks for immunization with the highest dose of $2 \times 10^{7} \mathrm{pfu}$ [110]. In the Geneva phase I/II, dose-finding, placebo-controlled, double-blind study the VSV-ZEBOV dose was reduced to $3 \times 10^{5}$ pfu compared to previous doses of $1-5 \times 10^{7} \mathrm{pfu}$ [111]. The lower dose improved tolerability, but decreased antibody responses. Moreover, it did not prevent vaccine-related arthritis, dermatitis, or vasculitis. 
A randomized, placebo-controlled phase III trial was conducted in 1500 adults with the chimpanzee Ad3 (ChAd3-EBO-Z) and the recombinant VSV (rVSVDG-ZEBOV-GP) vaccines in Liberia [112]. Adverse events including injection-site reactions, headache, fever, and fatigue occurred significantly more frequently in individuals receiving the active vaccine compared to placebo. Antibody responses were detected in $70.8 \%$ and $83.7 \%$ of subjects in the ChAd3-EBO-Z and the rVSV $\triangle$ G-ZEBOV-GP groups, respectively, compared to $2.8 \%$ in the placebo group one month after vaccination. At 12 months the percentage for the ChAd3-EBO-Z and the rVSV $\Delta$ G-ZEBOV-GP groups was $63.5 \%$ and $79.5 \%$, respectively, with $6.8 \%$ in the placebo group. Another phase III trial was conducted in Guinea as an open-label, cluster-randomized ring vaccination study in suspected cases of Ebola virus disease (EBV) [113]. A total number of 7651 individuals were included, of which 4123 persons were assigned for immediate vaccination with rVSV-ZEBOV and 3528 persons assigned for delayed vaccination. No cases of EBV were detected in the immediate vaccination group after 10 days, whereas 16 cases of EBV were registered in the delayed vaccination group. No new cases of EBV were diagnosed in either group. Overall, the rVSV-ZEBOV vaccine was confirmed to be safe and showed promise as highly efficient in preventing EBV. Another phase III study was conducted in Guinea and Sierra Leone applying a single intramuscular vaccination with $2 \times 10^{7}$ pfu of rVSV-ZEBOV [114]. In the randomized trial, 2119 individuals were immediately vaccinated and 2041 persons were vaccinated after a delay of 21 days after randomization. Vaccinated individuals were followed up for 84 days offering substantial protection against EBV with no cases of EBV discovered from day 10 after vaccination. Moreover, an individually-controlled phase II/III trial was conducted on health care and frontline workers in the five most EBV affected districts in Sierra Leone [115]. A single intramuscular dose was administered at enrollment or 18-24 weeks after enrollment. The outcome indicated that no EBV cases and no vaccine-related serious adverse events were reported. Finally, a randomized, double-blind, multicenter phase III trial was conducted in the United States, Spain, and Canada. [116]. Vaccination was taken place with doses of $2 \times 10^{7} \mathrm{pfu}$ and $1 \times 10^{8} \mathrm{pfu}$ of rVSV $\triangle$ G-ZEBOV-GP and placebo for the assessment of safety and immunogenicity. The vaccine was generally well-tolerated. Although systemic adverse events occurred in comparison to placebo, no vaccine-related severe adverse events or deaths were reported. Overall, the results confirmed the safety of vaccination of the EBV risk population with rVSV $\triangle$ G-ZEBOV-GP.

MV-Edm vaccine strains have been tested in clinical trials against breast, ovarian, head and neck cancer, glioblastoma, and myeloma [121,122]. In this context, an open-label, nonrandomized dose-escalation phase I trial was conducted with an unmodified vaccine strain MV-Edm Zagreb (MV-EZ) in patients with cutaneous T cell lymphomas [117]. Intratumor injections of MV-EZ on days 4 and 17 were preceded by subcutaneous IFN $\alpha$ injections ( 72 and $24 \mathrm{~h}$ prior to MV-EZ). The maximum tolerated dose was defined as $10^{3} \mathrm{TCID}_{50}$. Complete regression of CTCL lesions was observed in one patient, while partial regression was observed in the other patients. Related to recombinant $\mathrm{MV}$, a phase I trial was conducted in patients with advanced ovarian cancer by intraperitoneal injection of MV-CEA [118,123]. Administration of MV-CEA at doses of $10^{3}$ to $10^{9} \mathrm{TCID}_{50}$ confirmed no dose-limiting toxicity. The best objective response comprised stable disease in 14 patients with a median duration of 88 days and a range of 55 to 277 days. All individuals vaccinated with higher dose levels $\left(10^{7}-10^{9}\right.$ TCID 50$)$ accomplished stable disease, whereas only five out of 12 patients vaccinated with $10^{3}-10^{6} \mathrm{TCID}_{50}$ ) achieved it. MV-CEA has also been planned for a phase I clinical trial in patients with recurrent glioblastoma multiforme [119]. The study aims at treatment with a starting dose of $1 \times 10^{5} \mathrm{TCID}_{50}$ of MV-CEA escalating to the maximum dose level of $2 \times 10^{7} \mathrm{TCID}_{50}$. One group of patients will receive direct injections into the resection cavity and in the other group MV-CEA will be administered into recurrent tumors. So far, three patients have received $1 \times 10^{5} \mathrm{TCID} 50$ and three other patients $1 \times 10^{6} \mathrm{TCID}_{50}$ in the resection cavity showing no dose-limiting toxicity. Oncolytic MV vectors expressing the human sodium iodide symporter (NIS) have been subjected to a phase I trial [120]. Patients with relapsed refractory myeloma received intravenous MV-NIS or cyclophosphamide two days prior to MV-NIS treatment. The initial dose-escalation study $\left(1 \times 10^{6}-1 \times 10^{9} \mathrm{TCID}_{50}\right)$ revealed 
that the MTD was not reached. Therefore, doses of $1 \times 10^{10}$ and $1 \times 10^{11} \mathrm{TCID}_{50}$ were tested and the latter dose was planned to be used in a phase II trial. A complete response was observed in one patient treated with $1 \times 10^{11} \mathrm{TCID}_{50}$. The response persisted for 9 months after which an isolated relapse occurred in the skull without recurrent marrow involvement. Irradiation of the lesion resulted in the patient remaining disease-free for an additional 19 months. Another patient had subjective softening and shrinking of her extramedullary plasmacytomas of her back and thighs.

\section{Conclusions and Future Aspects}

In summary, numerous preclinical and clinical studies have confirmed the feasibility of the approach of applying self-replicating RNA viruses for both preventive and therapeutic use for various diseases (Tables 1-3). In this context, immunization with self-replicating RNA viruses has generated strong immune responses and in many cases provided protection against challenges with lethal doses of infectious agents. Moreover, administration of self-replicating RNA viral vectors expressing anticancer, toxic and/or immunostimulatory genes have demonstrated tumor growth inhibition, regression and even complete tumor eradication, which has supported significant prolongation of survival profiles. Immunization has also provided prophylactic protection against challenges with tumor cells in animal models. One interesting aspect of applying self-replicating RNA viruses comprises of the possibility of using RNA replicons, replication-deficient and -competent particles, and layered DNA/RNA vectors. It provides certain flexibility in choosing the means of delivery vehicle for specific applications. Moreover, several attempts have been made to engineer vectors specifically targeting, replicating and killing tumor cells. One approach has been to apply oncolytic viral vectors, which has provided specific killing of tumor cells without affecting normal cells [124]. In another approach, recombinant SFV particles were encapsulated in liposomes, which provided passive targeting of tumors and protection against recognition by the host immune system [106]. Moreover, the limitation of vector use due to host immune responses has been addressed by engineering a polymer-coated MV-NPL vector based on the MV Edmonston strain with the N, P, and L genes of the wild-type MV strain [125]. The polymer-coated MV-NPL showed superior oncolytic activity in vitro compared to naked MV-NPL. Moreover, polymer-coated MV-NPL provides higher complement-dependent cytotoxicity and antitumor activities than naked virus in mice. In the context of optimization of immune responses, specific targeting of DCs has proven a useful approach demonstrating enhanced immune responses from VEE vectors transducing DCs [72]. Recently, the delivery to DCs and translation of replicon RNA from classical swine fever virus (CSFV) encoding influenza virus NP, belonging to flaviviruses, was improved by lipid formulations, which was demonstrated both in vitro and in vivo by induced immune responses against influenza NP [126]. Moreover, potential enhanced therapeutic efficacy has been addressed by various applications of combination therapy. For instance, a triple treatment combination of sunitinib, low-dose irradiation, and SFV-HPV E6,7 particles rendered mice tumor-free [79]. Similarly, combining VSV immunization with ruxolitinib administration enhanced responses in both subcutaneous and orthotropic xenograft models [89]. Furthermore, ruxolitinib and Polybrene or DEAE-dextran rendered VSV-resistant cells susceptible, which should aid VSV-based therapy [93].

Although a relatively small number of clinical trials have been conducted with self-replicating RNA viruses, there has been some promising results. Especially, several phase III trials on MV-based vaccines against EBV have provided good safety profiles and protection [112-116]. Alphavirus vectors have been subjected to clinical trials on infectious diseases [102,103]. So far, elicited immune responses have been relatively modest, which at least to some extent has been related to lack of dose optimization. In the context of using self-replicating RNA viruses for cancer therapy, less progress has been seen compared to infectious diseases. However, VEE-CEA particles showed prolonged survival in a phase I trial in pancreatic cancer. Moreover, promising results were obtained for liposome encapsulated SFV particles (LipoVIL12) in terminally ill melanoma and kidney carcinoma patients [106]. Also, MV vectors 
have shown regression of lymphoma lesions, stable disease in treatment of ovarian cancer [118], and complete response in one myeloma patient [120].

One important issue related to the utilization of any delivery system is safety. In the first phase, it is essential to provide high safety standards during laboratory research and large-scale production to ensure the protection of personnel. Related to self-replicating RNA viruses, special attention has been paid to the engineering of helper virus vectors used for virus preparation both at laboratory and large-scale. Initially, introduction of point mutations in the p62 precursor of the SFV E2 and E3 envelope genes rendered generated recombinant particles conditionally infectious requiring an additional activation step with $\alpha$-chymotrypsin [127]. This second generation pSFV-Helper2 vector reduced the generation of replication-competent SFV particles to undetectable levels. Introduction of split helper systems for both SFV [128] and SIN [129] in which the capsid and envelope proteins are placed on separate plasmids generating high-titer particles eliminated production of recombinant-proficient alphavirus particles. Moreover, self-replicating RNA viruses-including alphaviruses, flaviviruses, MVs, and rhabdoviruses-have been classified at laboratory biosafety level 2 although the gene of interest expressed from the vector might impact the level [130]. Related to toxicity and adverse events observed in patients subjected to viral injections, VEE particles were well-tolerated, showed only local reactogenicity, and no clinically important changes [102]. However, although five serious adverse events were recorded in a phase I study in healthy HIV-uninfected individuals none were considered related to the vaccine [103]. The only adverse events related to immunization of Ebola patients with VSV vectors comprised of pain at the injection site, fatigue, myalgia, and headache [108]. Similarly, immunization of healthy volunteers with the VSV $\Delta$ G-ZEBOV-GP vaccine showed only mild to moderate self-limited adverse events and injection-site pain and headache during a 14-day follow-up period [109]. Related to toxicity issues, a phase I study in CRPC patients demonstrated that VEE-PSMA administration was well-tolerated and no toxicity was observed [105]. Likewise, was well-tolerated in ovarian cancer patients showing no dose-limiting toxicity, MV-CEA [123]. Interestingly, a phase I trial in pancreatic cancer patients showed the feasibility of repeated injections [104]. Moreover, liposome-encapsulated SFV-IL12 particles could be repeatedly administered to kidney carcinoma and melanoma patients without demonstrating any toxicity, or virus- or liposome-related immune responses [106].

Looking into the future, continuous vector development aiming at delivery and safety improvements will certainly support the progress in therapeutic applications of self-replicating RNA viral vectors. Moreover, dose optimization studies, especially at the clinical level, needs to be conducted. As vaccine development and gene therapy approaches have taken giants leaps recently with classical approaches and more pioneering efforts using viral vectors and nucleic acids. The attractive features of self-replicating RNA viruses relate to the easy of virus production, broad host range, high safety levels due to no risk of chromosomal integration, targeting of DCs, but most importantly the extreme RNA replication in the cytoplasm, which supports high level transgene expression as the basis for generating strong immune responses. Today, RNA-based delivery provides an attractive approach, especially combined with either polymer- or liposome-based encapsulation strategies.

Funding: No external funding was received.

Conflicts of Interest: The author declares no conflict of interest.

\section{References}

1. Burnett, J.C.; Rossi, J.J. RNA-based therapeutics: Current progress and future prospects. Chem. Biol. 2012, 19, 60-71. [CrossRef] [PubMed]

2. Hoy, S.M. Patisiran: First global approval. Drugs 2018, 78, 1625-1631. [CrossRef]

3. Sahin, U.; Kariko, K.; Türeci, O. mRNA-based therapeutics-developing a new class of drugs. Nat. Rev. Drug Discov. 2014, 13, 759-780. [CrossRef] [PubMed] 
4. Fotin-Mleczek, M.; Duchardt, K.M.; Lorenz, C.; Pfeiffer, R.; Ojkić-Zrna, S.; Probst, J.; Kallen, K.J. Messenger RNA-based vaccines with dual activity induce balanced TLR-7 dependent adaptive immune responses and provide antitumor activity. J. Immunother. 2011, 34, 1-15. [CrossRef]

5. Weide, B.; Pascolo, S.; Scheel, B.; Derhovanessian, E.; Pflugfelder, A.; Eigentler, T.K.; Pawelec, G.; Hoerr, I.; Rammensee, H.G.; Garbe, C. Direct injection of protamine-protected mRNA: Results of a phase $1 / 2$ vaccination trial in metastatic melanoma patients. J. Immunother. 2009, 32, 498-507. [CrossRef]

6. Petsch, B.; Schnee, M.; Vogel, A.B.; Lange, E.; Hoffmann, B.; Voss, D.; Schlake, T.; Thess, A.; Kallen, K.J.; Stitz, L.; et al. Protective efficacy of in vitro synthesized, specific mRNA vaccines against influenza A virus infection. Nat. Biotech. 2012, 30, 1210-1216. [CrossRef] [PubMed]

7. Allard, S.D.; De Keersmaecker, B.; de Goede, A.L.; Verschuren, E.J.; Koetsveld, J.; Reedijk, M.L.; Wylock, C.; De Bel, A.V.; Vandeloo, J.; Pistoor, F.; et al. A phase I/IIa immunotherapy trial of HIV-1-infected patients with Tat, Rev and Nef expressing dendritic cells followed by treatment interruption. Clin. Immunol. 2012, 142, 252-268. [CrossRef]

8. Kormann, M.S.; Hasenpusch, G.; Aneja, M.K.; Nica, G.; Flemmer, A.W.; Herber-Jonat, S.; Huppmann, M.; Mays, L.E.; Illenyi, M.; Schams, A.; et al. Expression of therapeutic proteins after delivery of chemically modified mRNA in mice. Nat. Biotech. 2011, 29, 154-157. [CrossRef]

9. Wang, H.; Yang, H.; Shivalila, C.S.; Dawlaty, M.M.; Cheng, A.W.; Zhang, F.; Jaenisch, R. One-step generation of mice carrying mutations in multiple genes by CRISPR/Cas mediated genome engineering. Cell 2013, 153, 910-918. [CrossRef]

10. Lundstrom, K. Self-replicating RNA viral vectors for vaccine development and gene therapy. Fut. Virol. 2016, 11, 345-356. [CrossRef]

11. Straus, J.H.; Strauss, E.G. The Alphaviruses: Gene expression, replication and evolution. Micobiol. Rev. 1994, 58, 491-562.

12. Pijlman, G.P.; Suhrbier, A.; Khromykh, A.A. Kunjin virus replicons: An RNA-based, non-cytopathic viral vector system for protein production, vaccine and gene therapy applications. Exp. Opin. Biol. Ther. 2006, 6, 134-145. [CrossRef] [PubMed]

13. Singh, M.; Cattaneo, R.; Billeter, M.A. A recombinant measles virus expressing hepatitis B surface antigen induces humoral responses in genetically modified mice. J. Virol. 1999, 73, 4823-4828. [PubMed]

14. Lyles, D.S.; Rupprecht, C.E. Rhabdoviridiae. In Fields' Virology, 5th ed.; Knipe, D.M., Howley, P.M., Eds.; Wolters Kluwer Health/Lippincott Williams \& Wilkins: Philadelphia, PA, USA, 2007; pp. 1364-1408.

15. Liljestrom, P.; Garoff, H. A new generation of animal cell expression vectors based on the Semliki Forest virus replicon. Biotechnology 1991, 9, 1356-1361. [CrossRef] [PubMed]

16. Xiong, C.; Levis, R.; Shen, P.; Schlesinger, S.; Rice, C.M.; Huang, H.V. Sindbis virus: An efficient, broad host range vector for gene expression in animal cells. Science 1989, 243, 1188-1191. [CrossRef] [PubMed]

17. Davis, N.L.; Willis, L.V.; Smith, J.F.; Johnston, R.F. In vitro synthesis of infectious Venezuelan equine encephalitis virus RNA from a cDNA clone: Analysis of a viable deletion mutant. Virology 1989, 171, 189-204. [CrossRef]

18. Lundstrom, K.; Schweitzer, C.; Rotmann, D.; Hermann, D.; Schneider, E.M.; Ehrengruber, M.U. Semliki Forest virus vectors: Efficient vehicles for in vitro and in vivo gene delivery. FEBS Lett. 2001, 504, 99-103. [CrossRef]

19. DiCiommo, D.P.; Bremner, R. Rapid, high level protein production using DNA-based Semliki Forest virus vectors. J. Biol. Chem. 1998, 273, 18060-18066. [CrossRef]

20. De Felipe, F. Skipping the co-expression problem: The new 2A 'CHYSEL' technology. Genet. Vaccines Ther. 2004, 2, 13. [CrossRef]

21. Khromykh, A.A.; Varnavski, A.N.; Westaway, E.G. Encapsidation of the flavivirus Kunjin replicon RNA by using a complementation system providing Kunjin virus structural proteins in trans. J. Virol. 1998, 72, 5967-5977.

22. Shi, P.Y.; Tilgner, M.; Lo, M.K. Construction and characterization of subgenomic replicons of New York strain of West Nile virus. Virology 2002, 296, 219-233. [CrossRef] [PubMed]

23. Scholle, I.; Girard, Y.A.; Zhao, Q.; Higgs, S.; Mason, P.W. Trans-packaged West Nile virus-like particles: Infectious properties in vitro and in infected mosquito vectors. J. Virol. 2004, 78, 11605-11614. [CrossRef]

24. Molenkamp, R.; Kooi, E.A.; Lucassen, M.A.; Greve, S.; Thijssen, J.C.; Spaan, W.J.; Bredenbeek, P.J. Yellow fever virus replicons as an expression system for hepatitis C virus structural proteins. J. Virol. 2003, 77, 1644-1648. [CrossRef] [PubMed] 
25. Jones, C.T.; Patkar, C.G.; Kuhn, R.J. Construction and applications of yellow fever virus replicons. Virology 2005, 331, 247-259. [CrossRef] [PubMed]

26. Jones, M.; Davidson, A.; Hibbert, L.; Gruenwald, P.; Schlaak, J.; Ball, S.; Foster, G.R.; Jacobs, M. Dengue virus inhibits alpha interferon signaling by reducing STAT2 expression. J. Virol. 2005, 79, 5414-5420. [CrossRef]

27. Pang, X.; Zhang, M.; Dayton, A.I. Development of dengue virus type 2 replicons capable of prolonged expression in host cells. BMC Microbiol. 2001, 1, 18.

28. Gherke, R.; Ecker, M.; Aberle, S.W.; Allison, S.L.; Heinz, F.X.; Mandi, C.W. Incorporation of tick-borne encephalitis virus replicons into virus-like particles by a packaging cell line. J. Virol. 2003, 77, 8924-8933. [CrossRef]

29. Hayasaka, D.; Yoshii, K.; Ueki, T.; Goto, A.; Mizutani, T.; Kariwa, H.; Iwasaki, T.; Gould, E.A.; Takashima, I. Sub-genomic replicons of tick-borne encephalitis virus. Arch. Virol. 2004, 149, 1245-1256. [CrossRef]

30. Radecke, F.; Spielhofer, P.; Schneider, H.; Kaelin, K.; Huber, M.; Dötsch, C.; Christiansen, G.; Billeter, M.A. Rescue of measles viruses from cloned DNA. EMBO J. 1995, 14, 5773-5784. [CrossRef]

31. Osakada, F.; Callaway, E.M. Design and generation of recombinant rabies virus vectors. Nat. Protoc. 2013, 8 , 1583-1601. [CrossRef]

32. An, H.; Kim, G.N.; Kang, C.Y. Genetically modified VSV(NJ) vector is capable of accommodating a large foreign gene insert and allows high level gene expression. Virus Res. 2013, 171, 168-177. [CrossRef] [PubMed]

33. Harty, R.N.; Brown, M.E.; Hayes, F.P.; Wright, N.T.; Schnell, M.J. Vaccinia virus-free recovery of vesicular stomatitis virus. J. Mol. Microbiol. Biotechnol. 2001, 3, 513-517. [PubMed]

34. Ohara, S.; Inoue, K.; Yamada, M.; Yamawaki, T.; Koganezawa, N.; Tsuttsui, K.; Witter, M.P.; Iijima, T. Dual transneural tracing in the rat entorhoinal-hippocampal circuit by intracerebral injection of recombinant rabies virus vectors. Front. Neuroanat. 2009, 3, 1-11. [CrossRef] [PubMed]

35. Ito, N.; Takayama-Ito, M.; Yamada, K.; Hosokawa, J.; Sugiyama, M.; Minamoto, N. Improved recovery of rabies virus from cloned cDNA using a vaccinia virus-free reverse genetics system. Microbiol. Immunol. 2003, 47, 613-617. [CrossRef] [PubMed]

36. Dorange, F.; Piver, E.; Bru, T.; Collin, C.; Roingeard, P.; Pagés, J.C. Vesicular stomatitis virus glycoprotein: A transducing coat for SFV-based RNA vectors. J. Gene Med. 2004, 6, 1014-1022. [CrossRef] [PubMed]

37. Harahap-Carrillo, I.S.; Ceballos-Olvera, I.; Valle, J.R. Immunogenic subviral particles displaying domain III of dengue 2 envelope protein vectored by measles virus. Vaccines 2015, 3, 503-518. [CrossRef] [PubMed]

38. Hu, H.M.; Chen, H.W.; Hsiao, Y.; Wu, S.H.; Chung, H.H.; Hsieh, C.H.; Chong, P.; Leng, C.H.; Pan, C.H. The successful induction of $\mathrm{T}$-cell and antibody responses by a recombinant measles virus-vectored tetravalent dengue vaccine provides partial protection against dengue-2 infection. Hum. Vaccin. Immunother. 2016, 12, 1678-1689. [CrossRef]

39. Pyankov, O.V.; Bodnev, S.A.; Pyankova, O.G.; Solodkyi, V.V.; Pyankov, S.A.; Setoh, Y.X.; Volchokova, V.A.; Suhrbier, A.; Volchikov, V.V.; Agafonov, A.A.; et al. A Kunjin replicon virus-like vaccine provides protection against Ebola virus infection in nonhuman primates. J. Infect. Dis. 2015, 212 (Suppl. S2), S368-S371. [CrossRef]

40. Marzi, A.; Robertson, S.J.; Haddock, E.; Feldmann, F.; Hanley, P.W.; Scott, D-P.; Strong, J.E.; Kobinger, G.; Best, S.M.; Feldmann, H. Ebola vaccine. VSV-EBOV rapidly protects macaques against infection with the 2014/2015 Ebola virus outbreak strain. Science 2015, 349, 739-742. [CrossRef]

41. Geisbert, T.W.; Feldmann, H. Recombinant vesicular stomatitis virus-based vaccines against Ebola and Marburg infections. J. Infect. Dis. 2011, 204 (Suppl. S3), S1075-S1081. [CrossRef]

42. Wilson, J.A.; Hart, M.K. Protection from Ebola virus mediated by cytotoxic T-lymphocytes specific for the viral nucleoprotein. J. Virol. 2001, 75, 2660-2664. [CrossRef] [PubMed]

43. Pushko, P.; Bray, M.; Ludwig, G.V.; Parker, M.; Schmaljohn, A.; Sanchez, A.; Jahrling, P.B.; Smith, J.F. Recombinant RNA replicons derived from attenuated Venezuelan equine encephalitis virus protect guinea pigs and mice from Ebola hemorrhagic fever virus. Vaccine 2000, 19, 142-153. [CrossRef]

44. Öhlund, P.; Garcia-Arriaza, J.; Zusinaite, E.; Szurgot, I.; Mànnik, A.; Kraus, A.; Ustav, M.; Merits, A.; Esteban, M.; Liljestrom, P.; et al. DNA-launched RNA replicon vaccines induce potent anti-Ebola immune responses that can be further improved by a recombinant MVA boost. Sci. Rep. 2018, 8, 12459. [CrossRef]

45. Del Valle, J.R.; Devaux, P.; Hodge, G.; Wegner, N.J.; McChesney, M.B.; Cattaneo, R. A vectored measles virus induces hepatitis B surface antigen antibodies while protecting macaques against virus challenge. J. Virol. 2007, 81, 10597-10605. [CrossRef] [PubMed] 
46. Reynolds, T.D.; Buonocore, L.; Rose, N.F.; Rose, J.K.; Robek, M.D. Virus-like vesicle-based therapeutic vaccine vectors for chronic hepatis B virus infection. J. Virol. 2015, 89, 10407-10415. [CrossRef]

47. Brand, D.; Lemiale, F.; Turbica, I.; Buzelay, L.; Brunet, S.; Barin, F. Comparative analysis of humoral immune responses to HIV type 1 envelope glycoproteins in mice immunized with a DNA vaccine, recombinant Semliki Forest virus RNA, or recombinant Semliki Forest virus particles. AIDS Res. Hum. Retroviruses 1998, 14, 1369-1377. [CrossRef]

48. Giraud, A.; Ataman-Onal, Y.; Battail, N. Generation of monoclonal antibodies to native human immunodeficiency virus type 1 envelope glycoprotein by immunization of mice with naked RNA. J. Virol. Methods 1999, 79, 75-84. [CrossRef]

49. Ajbani, S.P.; Velhal, S.M.; Kadam, R.B.; Patel, V.V.; Lundstrom, K.; Bandivdekar, A.H. Immunogenicity of virus-like Semliki Forest virus replicon particles expressing Indian HIV-1C gag, env and pol RT genes. Immunol. Lett. 2017, 190, 221-232. [CrossRef]

50. Knudsen, M.L.; Ljungberg, K.; Tatoud, R.; Weber, J.; Esteban, M.; Liljestrom, P. Alphavirus replicon DNA expressing HIV antigens is an excellent prime for boosting with recombinant modified vaccinia Ankara (MVA) or with HIV gp140 protein antigen. PLoS ONE 2015, 10, e0117042. [CrossRef]

51. Malone, J.G.; Berglund, P.J.; Liljestrom, P.; Rhodes, G.H.; Malone, R.W. Mucosal immune responses associated with polynucleotide vaccination. Behring Inst. Mitt. 1997, 98, 63-72.

52. Schultz-Cherry, S.; Dybing, J.K.; Davis, N.L.; Williamson, C.; Suarez, D.L.; Johnston, R.; Perdue, M.L. Influenza virus (A/HK/156/97) hemagglutinin expressed by an alphavirus replicon system protects against lethal infection with Hong Kong-origin H5N1 viruses. Virology 2000, 278, 55-59. [CrossRef] [PubMed]

53. Fleeton, M.N.; Chen, M.; Berglund, P.; Rhodes, G.; Parker, S.E.; Murphy, M.; Atkins, G.J.; Liljestrom, P. Self-replicative RNA vaccines elicit protection against influenza A virus, respiratory syncytial virus, and a tickborne encephalitis virus. J. Infect. Dis. 2001, 183, 1395-1398. [CrossRef] [PubMed]

54. Vogel, A.B.; Lambert, L.; Kinnear, E.; Busse, D.; Erbar, S.; Reufer, K.C.; Wicke, L.; Perkovic, M.; Beissert, T.; Haas, H.; et al. Self-amplifying RNA vaccines give equivalent protection against influenza to mRNA vaccines but at much lower doses. Mol. Ther. 2018, 26, 446-455. [CrossRef] [PubMed]

55. Safronetz, D.; Mire, C.; Rosenke, K.; Feldmann, F.; Haddock, E.; Geissbert, T.; Feldmann, H. A recombinant vesicular stomatitis virus-based Lassa fever vaccine protects guinea pigs and macaques against challenge with geographically and genetically distinct Lassa viruses. PLoS Negl. Trop. Dis. 2015, 9, e0003736. [CrossRef] [PubMed]

56. Wang, M.; Jokinen, J.; Tretvakova, I.; Pushko, P.; Lukashevich, I.S. Alphavirus vector-based replicon particles expressing multivalent cross-protective Lassa virus glycoproteins. Vaccine 2018, 36, 683-690. [CrossRef] [PubMed]

57. Kainulainen, M.H.; Spengler, J.R.; Welch, S.R.; Coleman-McCray, J.D.; Harmon, J.R.; Klena, J.D.; Nichol, S.T.; Albarino, C.G.; Spiropoulou, C.F. Use of a scalable replicon-particle vaccine to protect against lethal Lassa virus infection in the guinea pig model. J. Infect. Dis. 2018, 217, 1957-1966. [CrossRef] [PubMed]

58. Malczyk, A.H.; Kupke, A.; Prüfer, S.; Scheuplein, V.A.; Hutzler, S.; Kreuz, D. A highly immunogenic and protective Middle East respiratory syndrome coronavirus vaccine based on a recombinant measles virus vaccine platform. J. Virol. 2015, 89, 11654-11667. [CrossRef] [PubMed]

59. Sheahan, T.; Whitmore, A.; Long, K.; Ferris, M.; Rockx, B.; Funkhouser, W. Successful vaccination strategies that protect aged mice from lethal challenge from influenza virus and heterologous severe acute respiratory syndrome coronavirus. J. Virol. 2011, 85, 217-230. [CrossRef]

60. Bates, J.T.; Pickens, J.A.; Schuster, J.E.; Johnson, M.; Tollefson, S.J.; Williams, J.V. Immunogenicity and efficacy of alphavirus derived replicon vaccines for respiratory syncytial virus and human metapneumovirus in nonhuman primates. Vaccine 2016, 34, 950-956. [CrossRef]

61. Geall, A.J.; Verma, A.; Otten, G.R.; Shaw, C.A.; Hekele, A.; Banerjee, K. Nonviral delivery of self-amplifying RNA vaccines. Proc. Natl. Acad. Soc. USA 2012, 109, 14604-14609. [CrossRef]

62. Anraku, I.; Mokhonov, V.V.; Rattanasena, P.; Mokhonova, E.I.; Leung, J.; Pijlman, G.; Cara, A.; Schroder, W.A.; Khromykh, A.A.; Suhrbier, A. Kunjin replicon-based simian immunodeficiency virus gag vaccines. Vaccine 2008, 26, 3268-3276. [CrossRef] [PubMed] 
63. Nillsson, C.; Mäkitalo, B.; Berglund, P.; Bex, F.; Liljeström, P.; Sutter, G. Enhanced simian immunodeficiency virus-specific immune responses in macaques induced by priming with recombinant Semliki Forest virus and boosting with modified vaccinia virus Ankara. Vaccine 2001, 19, 3526-3536. [CrossRef]

64. Kamrud, K.I.; Coffield, V.M.; Owens, G.C.; Alterson, K.; Custer, M. In vitro and in vivo characterization of microRNA-targeted alphavirus replicon and helper RNAs. J. Virol. 2010, 84, 7713-7725. [CrossRef] [PubMed]

65. Bhomia, M.; Sharma, A.; Gayen, M. Artificial microRNAs can effectively inhibit replication of Venezuelan equine encephalitis virus. Antivir. Res. 2013, 100, 429-434. [CrossRef] [PubMed]

66. Paraskevakou, G.; Allen, C.; Nakamura, T.; Zollman, P.; James, C.D.; Peng, K.W. Epidermal growth factor receptor (EGFR)retargeted measles virus strains effectively target EGFR- or EGFRvIII expressing gliomas. Mol. Ther. 2007, 15, 677-686. [CrossRef] [PubMed]

67. Yamanaka, R.; Zullo, S.A.; Ramsey, J.; Onodera, M.; Tanaka, R.; Blaese, M. Induction of therapeutic antitumor antiangiogenesis by intratumoral injection of genetically engineered endostatin-producing Semliki Forest virus. Cancer Gene Ther. 2001, 8, 796-802. [CrossRef] [PubMed]

68. Martikainen, M.; Niittykoski, M.; von und zu Frauenberg, M.; Immonen, A.; Koponen, S. MicroRNA-attenuated clone of virulent Semliki Forest virus overcomes antiviral type I interferon in resistant mouse CT-2A glioma. J. Virol. 2015, 89, 10637-10647. [CrossRef]

69. McDonald, C.J.; Erlichman, C.; Ingle, J.N.; Rosales, G.A.; Allen, C.; Greiner, S.M. A measles virus vaccine strain derivative as a novel oncolytic agent against breast cancer. Breast Cancer Res. Treat. 2006, 99, 177-184. [CrossRef]

70. Wang, X.; Wang, J.P.; Rao, X.M.; Price, J.E.; Zhou, H.S.; Lachman, L.B. Prime-boost vaccination with plasmid and adenovirus gene vaccines control HER2/neu+ metastatic breast cancer in mice. Breast Cancer Res. 2005, 7, R580-R588. [CrossRef]

71. Moran, T.P.; Burgents, J.E.; Long, B. Alphaviral vector-transduced dendritic cells are successful therapeutic vaccines against neu-overexpressing tumors in wild-type mice. Vaccine 2007, 25, 6604-6612. [CrossRef]

72. Lyons, J.A.; Sheahan, B.J.; Galbraith, S.E. Inhibition of angiogenesis by a Semliki Forest virus vector expressing VEGFR-2 reduces tumour growth and metastasis in mice. Gene Ther. 2007, 14, 503-513. [CrossRef] [PubMed]

73. Hoang-Le, D.; Smeenk, L.; Anraku, I.; Pijlman, G.P.; Wang, X.P.; de Vrij, J. A Kunjin replicon vector encoding granulocyte macrophage colony-stimulating factor for intra-tumoral gene therapy. Gene Ther. 2009, 16, 190-199. [CrossRef] [PubMed]

74. Ying, H.; Zaks, T.Z.; Wang, R.-F.; Irvine, K.R.; Kammula, U.S.; Marincola, F.M. Cancer therapy using a self-replicating RNA vaccine. Nat. Med. 1999, 5, 823-827. [CrossRef] [PubMed]

75. Velders, M.P.; McElhiney, S.; Cassetti, M.C.; Eiben, G.L.; Higgins, T.; Kovacs, G.R. Eradication of established tumors by vaccination with Venezuelan equine encephalitis virus replicon particles delivering human papillomavirus 16 E7 RNA. Cancer Res. 2001, 61, 7861-7867.

76. Daemen, T.; Riezebos-Brilman, A.; Bungener, L.; Regts, J.; Dontje, B.; Wilschut, J. Eradication of established HPV16-transformed tumours after immunisation with recombinant Semliki Forest virus expressing a fusion protein of E6 and E7. Vaccine 2000, 21, 1082-1088. [CrossRef]

77. Van de Wall, S.; Ljungberg, K.; Ip, P.P.; Boerma, A.; Knudsen, M.L.; Nijman, H.W. Potent therapeutic efficacy of an alphavirus replicon DNA vaccine expressing human papilloma virus E6 and E7 antigens. Oncoimmunology 2018, 7, e1487913. [CrossRef] [PubMed]

78. Draghiciu, O.; Walczak, M.; Hoogeboom, B.N.; Franken, K.L.; Melief, K.J.; Nijman, H.W. Therapeutic immunization and local low-dose tumor irradiation, a reinforcing combination. Int. J. Cancer 2014, 134, 859-872. [CrossRef] [PubMed]

79. Draghiciu, O.; Boerma, A.; Hoogeboom, B.N.; Nijman, H.W.; Daemen, T. A rationally designed combined treatment with an alphavirus-based cancer vaccine, sunitinib and low-dose tumor irradiation completely blocks tumor development. Oncoimmunology 2015, 4, e1029699. [CrossRef]

80. Lee, Y.R.; Su, C.Y.; Chow, N.H.; Lai, W.W.; Lei, H.Y.; Chang, C.L. Dengue viruses can infect human primary lung epithelia as well as lung carcinoma cells and can also induce the secretion of IL-6 and RANTES. Virus Res. 2007, 126, 216-225. [CrossRef]

81. Murphy, A.M.; Morris-Downes, M.M.; Sheahan, B.J.; Atkins, G.J. Inhibition of human lung carcinoma cell growth by apoptosis induction using Semliki Forest virus recombinant particles. Gene Ther. 2000, 7 , 1477-1482. [CrossRef] 
82. Määttä, A.M.; Mäkinen, K.; Ketola, A.; Liimatainen, T.; Yongabi, F.N.; Vähä-Koskela, M. Replication competent Semliki Forest virus prolongs survival in experimental lung cancer. Int. J. Cancer 2008, 123, 1704-1711. [CrossRef] [PubMed]

83. Fujiyuki, T.; Yoneda, M.; Amagai, Y.; Obayashi, K.; Ikeda, F.; Shoji, K. A measles virus selectively blind to signalling lymphocytic activation molecule shows anti-tumor activity against lung cancer cells. Oncotarget 2015, 6, 24895-24903. [CrossRef] [PubMed]

84. McAllister, A.; Arbetman, A.E.; Mandl, S.; Pena-Rossi, C.; Andino, R. Recombinant yellow fever viruses are effective therapeutic vaccines for treatment of murine solid tumors and pulmonary metastases. J. Virol. 2000, 74, 9197-9205. [CrossRef] [PubMed]

85. Avogadri, F.; Merghoub, T.; Maughan, M.F.; Hirschhorn-Cymerman, D.; Morris, J.; Ritter, E. Alphavirus replicon particles expressing TRP-2 provide potent therapeutic effect on melanoma through activation of humoral and cellular immunity. PLoS ONE 2010, 5, e12670. [CrossRef] [PubMed]

86. Avogadri, F.; Zappasodi, R.; Yang, A.; Budhu, S.; Malandro, N.; Hisrchhorn-Cymerman, D. Combination of alphavirus replicon particle-based vaccination with immunomodulatory antibodies: Therapeutic activity in the B16 melanoma mouse model and immune correlates. Cancer Immunol. Res. 2014, 2, 448-458. [CrossRef] [PubMed]

87. Yin, X.; Wang, W.; Zhu, X.; Wang, Y.; Wu, S.; Wang, Z. Synergistic antitumor efficacy of combined DNA vaccines targeting tumor cells and angiogenesis. Biochem. Biophys. Res. Comm. 2015, 465, 239-244. [CrossRef] [PubMed]

88. Kimpel, J.; Urbiola, C.; Koske, I.; Tober, R.; Banki, Z.; Wollmann, G. The Oncolytic virus VSV-GP is effective against malignant melanoma. Viruses 2018, 10, 108. [CrossRef]

89. Dold, C.; Rodriguez-Urbiola, C.; Wollmann, G.; Egerer, L.; Muikk, A.; Bellmann, L. Application of interferon modulators to overcome partial resistance of human ovarian cancers to VSV-GP oncolytic therapy. Mol. Ther. Oncolytics 2016, 3, 16021. [CrossRef]

90. Granot, T.; Meruelo, D. The role of natural killer cells in combinatorial anti-cancer therapy using Sindbis viral vector and irinotecan. Cancer Gene Ther. 2012, 19, 588-591. [CrossRef]

91. Zhang, Y.Q.; Tsai, Y.C.; Monie, A.; Wu, T.C.; Hung, C.F. Enhancing the therapeutic effect against ovarian cancer through a combination of viral oncolysis and antigen-specific immunotherapy. Mol. Ther. 2010, 18, 692-699. [CrossRef]

92. Murphy, A.M.; Besmer, D.M.; Moerdyk-Schauwecker, M.; Moestl, N.; Ornelles, D.A.; Mukherjee, P. Vesicular stomatitis virus as an oncolytic agent against pancreatic ductal adenocarcinoma. J. Virol. 2012, 86, 3073-3087. [CrossRef] [PubMed]

93. Felt, S.A.; Droby, G.N.; Grdzelishvili, V.Z. Ruxolitinib and polycation combination treatment overcomes multiple mechanisms of resistance of pancreatic cancer cells to oncolytic vesicular stomatitis virus. J. Virol. 2017, 91. [CrossRef] [PubMed]

94. Awano, M.; Fujiyuki, T.; Shoji, K.; Amagai, Y.; Murakami, Y.; Furukawa, Y. Measles virus selectively blind to signalling lymphocyte activity molecule has oncolytic efficacy against nectin-4-expressing pancreatic cancer cells. Cancer Sci. 2016, 107, 1647-1652. [CrossRef] [PubMed]

95. Msaouel, P.; Iankov, I.D.; Allen, C.; Morris, J.C.; von Messling, V.; Cattaneo, R. Engineered measles virus as a novel oncolytic therapy against prostate cancer. Prostate 2009, 69, 82-91. [CrossRef] [PubMed]

96. Durso, R.J.; Andjelic, S.; Gardner, J.P.; Margitich, D.J.; Donovan, G.P.; Arrigale, R.R. A novel alphavirus vaccine encoding prostate-specific membrane antigen elicits potent cellular and humoral immune responses. Clin. Cancer Res. 2007, 13, 3999-4008. [CrossRef] [PubMed]

97. Garcia-Hernandez, M.L.; Gray, A.; Hubby, B.; Kast, W.M. In vivo effects of vaccination with six-transmembrane epithelial antigen of the prostate: A candidate antigen for treating prostate cancer. Cancer Res. 2007, 67, 1344-1351. [CrossRef]

98. Garcia-Hernandez, M.L.; Gray, A.; Hubby, B.; Klinger, O.J.; Kast, W.M. Prostate stem cell antigen vaccination induces a long-term protective immune response against prostate cancer in the absence of autoimmunity. Cancer Res. 2008, 68, 861-869. [CrossRef]

99. Urbiola, C.; Santer, F.R.; Petersson, M.; van der Pluijm, G.; Horninger, W.; Erlmann, P. Oncolytic activity of the rhabdovirus VSV-GP against prostate cancer. Int. J. Cancer 2018, 143, 1786-1796. [CrossRef] 
100. Patel, M.R.; Jacobson, B.A.; Ji, Y.; Drees, J.; Tang, S.; Xiong, K. Vesicular stomatitis virus expressing interferon- $\beta$ is oncolytic and promotes antitumor immune responses in a syngeneic murine model of non-small cell lung cancer. Oncotarget 2015, 6, 33165-33177. [CrossRef]

101. Muik, A.; Kneiske, I.; Werbizki, M.; Wilflingseder, D.; Giroglou, T.; Ebert, O. Pseudotyping vesicular stomatitis virus with lymphocytic choriomeningitis virus glycoproteins enhances infectivity for glioma cells and minimizes neurotropism. J. Virol. 2011, 85, 5679-5684. [CrossRef]

102. Bernstein, D.I.; Reap, E.A.; Katen, K.; Watson, A.; Smith, K.; Norberg, P. Randomized, double-blind, phase I trial on an alphavirus replicon vaccine for cytomegalovirus in CMV negative volunteers. Vaccine 2010, 28, 484-493. [CrossRef] [PubMed]

103. Wecker, M.; Gilbert, P.; Russell, N.; Hural, J.; Allen, M.; Pensiero, M. Phase I safety and immunogenicity evaluations of an alphavirus replicon HIV-1 subtype C gag vaccine in healthy HIV-1-uninfected adults. Clin. Vaccine Immunol. 2012, 19, 1651-1660. [CrossRef] [PubMed]

104. Morse, M.A.; Hobelka, A.C.; Osada, T.; Berglund, P.; Hubby, B.; Negri, S. An alphavirus vector overcomes the presence of neutralizing antibodies and elevated numbers of Tregs to induce immune responses in humans with advanced cancer. J. Clin. Investig. 2010, 120, 3234-3241. [CrossRef] [PubMed]

105. Slovin, S.F.; Kehoe, M.; Durso, R.; Fernandez, C.; Olson, W.; Gao, J.P. A phase I dose escalation trial of vaccine replicon particles (VRP) expressing prostate-specific membrane antigen (PSMA) in subjects with prostate cancer. Vaccine 2013, 31, 943-949. [CrossRef] [PubMed]

106. Lundstrom, K. Biology and application of alphaviruses in gene therapy. Gene Ther. 2005, 12 (Suppl. S1), S92-S97. [CrossRef]

107. Suder, E.; Furuyama, W.; Feldmann, H.; Marzi, A.; de Wit, E. The vesicular stomatitis virus-based Ebola virus vaccine: From concept to clinical trials. Hum. Vaccin. Immunother. 2018, 14, 2107-2113. [CrossRef] [PubMed]

108. Regules, J.A.; Beigel, J.H.; Paolino, K.M.; Voell, J.; Castellano, A.R.; Hu, Z. A recombinant vesicular stomatitis virus ebola vaccine. N. Engl. J. Med. 2017, 376, 330-341. [CrossRef] [PubMed]

109. ElSherif, M.S.; Brown, C.; MacKinnon-Cameron, D.; Li, L.; Racine, T.; Alimonti, J. Assessing the safety and immunogenicity of recombinant vesicular stomatitis virus Ebola vaccine in healthy adults: A randomized clinical trial. CMAJ 2017, 189, E819-E827. [CrossRef] [PubMed]

110. Dahlke, C.; Kasonta, R.; Lunemann, S.; Krahling, V.; Zinser, M.E.; Biedenkopf, N. Dose-dependent T-cell dynamics and cytokine cascade following rVSV-ZEBOV immunization. EBioMedicine 2017, 19, 107-118. [CrossRef]

111. Huttner, A.; Dayer, J.A.; Yerly, S.; Combescure, C.; Auderset, F.; Desmeules, J. The effect of dose on the safety and immunogenicity of the VSV Ebola candidate vaccine: A randomised double-blind, placebo-controlled phase 1/2 trial. Lancet Infect. Dis. 2015, 15, 1156-1166. [CrossRef]

112. Kennedy, S.B.; Bolay, F.; Kieh, M.; Grandits, G.; Badio, M.; Ballou, R. Phase 2 placebo-controlled trial of two vaccines to prevent ebola in Liberia. N. Eng. J. Med. 2017, 377, 1438-1447. [CrossRef] [PubMed]

113. Henao-Restrepo, A.M.; Longini, I.M.; Egger, M.; Dean, N.E.; Edmunds, W.J.; Camacho, A. Efficacy and effectiveness of an rVSV-vectored vaccine expressing Ebola surface glycoprotein: Interim results from the Guinea ring vaccination cluster-randomised trial. Lancet 2015, 386, 857-866. [CrossRef]

114. Henao-Restrepo, A.M.; Camacho, A.; Longini, I.M.; Watson, C.H.; Edmunds, W.J.; Egger, M. Efficacy and effectiveness of an rVSV-vectored vaccine in preventing Ebola virus disease: Final results from the Guinea ring vaccination, open-label, cluster-randomised trial (Ebola Ca Suffit!). Lancet 2017, 389, 505-518. [CrossRef]

115. Widdowson, M.; Schrag, S.; Carter, R.; Carr, W.; Legardy-Williams, J.; Gibson, L. Implementing an Ebola vaccine study—Sierra leone. MMWR Suppl. 2016, 65, 98-106. [CrossRef] [PubMed]

116. Halperin, S.A.; Arribas, J.R.; Rupp, R.; Andrews, C.P.; Chu, L.; Das, R. Six-month safety data of recombinant vesicular stomatitis virus-zaire ebola virus envelope glycoprotein vaccine in a phase 3 double-blind, placebo-controlled randomized study in healthy adults. J. Infect. Dis. 2017, 215, 1789-1798. [CrossRef] [PubMed]

117. Heinzerling, L.; Künzi, V.; Oberholzer, P.A.; Kündig, T.; Naim, H.; Dummer, R. Oncolytic measles virus in cutaneous T-cell lymphomas mounts antitumor immune responses in vivo and targets interferon-resistant tumor cells. Blood 2005, 106, 2287-2294. [CrossRef] [PubMed]

118. Oncolytic Virus Therapy in Treating Patients with Progressive, Recurrent, or Refractory Ovarian Epithelial Cancer or Primary Peritoneal Cancer. Available online: http://www.clinicaltrials.gov/ct2/show/ NCT00408590 (accessed on 11 November 2018). 
119. Viral Therapy in Treating Patients with Recurrent Glioblastoma Multiforme. Available online: http://www. clinicaltrials.gov/ct2/show / NCT00390299 (accessed on 12 November 2018).

120. Dispenzieri, A.; Tong, C.; La Plant, B.; Lacy, M.Q.; Laumann, K.; Dingli, D. Phase I trial of systemic administration of Edmonston strain of measles virus genetically engineered to express the sodium iodide symporter in patients with recurrent or refractory multiple myeloma. Leukemia 2017, 31, 2791-2798. [CrossRef] [PubMed]

121. Msaouel, P.; Dispenzieri, A.; Galanis, E. Clinical testing of engineered oncolytic measles virus strains in the treatment of cancer. Curr. Opin. Mol. Ther. 2009, 11, 43-53. [PubMed]

122. Msaouel, P.; Opyrchal, M.; Dispenzieri, A.; Peng, K.W.; Federspiel, M.J.; Russell, S.J. Clinical trials with oncolytic Measles virus: Current status and future prospects. Curr. Cancer Drug Targets 2018, 18, 177-187. [CrossRef] [PubMed]

123. Galanis, E.; Hartmann, L.C.; Cliby, W.; Peethambaram, P.P.; Long, H.J.; Kaur, J.S. Phase I trial of intraperitoneal (IP) administration of a measles virus (MV) derivative expressing the human carcinoembryonic antigen (CEA) in recurrent ovarian cancer (OvCa). Cancer Res. 2010, 70, 875-882. [CrossRef]

124. Lundstrom, K. New frontiers in oncolytic viruses: Optimizing and selecting for virus strains with improved efficacy. Biologics 2018, 12, 43-60. [CrossRef] [PubMed]

125. Nosaki, K.; Hamada, K.; Takashima, Y.; Sagara, M.; Matsumura, Y.; Miyamoto, S. A novel, polymer-coated oncolytic measles virus overcomes immune suppression and induces robust antitumor activity. Mol. Ther. Oncolytics 2016, 3, 16022. [CrossRef] [PubMed]

126. Englezou, P.C.; Sapet, C.; Démoulins, T.; Milona, P.; Ebensen, T.; Schulze, K. Self-amplifying replicon RNA delivery to dendritic cells by cationic lipids. Mol. Ther. Nucleic Acids 2018, 12, 118-134. [CrossRef] [PubMed]

127. Berglund, P.; Sjöberg, M.; Garoff, H.; Atkins, G.J.; Sheahan, B.J.; Liljeström, P. Semliki Forest virus expression system: Production of conditionally infectious recombinant particles. Biotechnology 1993, 11, 916-920. [CrossRef] [PubMed]

128. Smerdou, C.; Liljeström, P. Two-helper system for production of recombinant Semliki Forest virus particles. J. Virol. 1999, 73, 1092-1098.

129. Ketola, A.; Schlesinger, S.; Wahlfors, J. Properties of Sindbis virus vectors produced with a chimeric split helper system. Int. J. Mol. Med. 2005, 15, 999-1003. [CrossRef] [PubMed]

130. Biosafety Levels for Biological Agents. Available online: https://ehs.stanford.edu/reference/biosafetylevels-biological-agents (accessed on 10 December 2018).

(C) 2018 by the author. Licensee MDPI, Basel, Switzerland. This article is an open access article distributed under the terms and conditions of the Creative Commons Attribution (CC BY) license (http:/ / creativecommons.org/licenses/by/4.0/). 